\title{
Gênese "ateneísta" da história cultural latino-americana
}

Jorge Myers

Tradução de Paul o Neves

Introdução: o momento de "Tierra Firme"

$\mathrm{N}$ a década de 1940, e no quadro do intenso movimento editorial que a diáspora espanhola - provocada pela guerra civil eo franquismo - estimulara nos diversos países da América Latina, um novo campo (ou subcampo) disciplinar começou a adquirir contornos precisos: a história cultural latino-americana. Era uma história que definia seu projeto cultural em torno dequatro traços muito espeć́ficos. Primeiro, utilizava um conceito de "cultura" que permanecia estreitamente ligado às noções alemãs de Kultur e Geist, tal como elas haviam sido elaboradas no curso dos debates sobre a Geistgeschichte [H istória do espírito], a Kulturgeschichte [H istória da cultura] e a Lebensphilosophie [Filosofia da vida] durante as primeiras décadas do sé culo XX. D ito de outro modo, essa história empregava uma definição do vocábulo "cultura" que tendia a enfatizar simultaneamente seu caráter "espiritual" e sua restrição ao universo da produção cultural da elite (embora esse último elemento tendesse a ficar muito atenuado nos textos produzidos por essa corrente). Segundo, postulava a existência de uma "cultura latino-americana" cujos traços gerais eram compartilhados por todas as nações dessa região: as inegáveis diferenças culturais que separavam uma nação de outra apareciam como menos importantes - desse ponto de vista - do que as semelhanças que as uniam. Essa corrente historiográfica possuía uma ter- 
1. As observações a esse respeito, feitas por Gilberto Freyre(1968, pp. 44-45), parecem aplicarseàmaioria dosintelectuais quae integraram essa formação cultural. cei ra característica que, embora menos definidora que as anteriores, constituiu um traço diferencial ante as tradições dominantes na mai oria das historiografias nacionais da região: ela propunha reivindicar a continuidade entre a experiência cultural ibérica ea das nações do N ovo M undo, efetuando desse modo uma espécie de "normalização historiográfica" do período coIonial. Finalmente, uma quarta característica que definiu essa nova história cultural foi sua predisposição a entabular um frutífero diálogo com as disciplinas da antropologia - Franz Boas e Robert Redfield aparecem nesses livros como "pensadores-guias" - e da sociologia - Simmel, Weber e D urkheim são presenças constantes, embora difusas, já que o contato com suas obras se deu muitas vezes por via indireta ${ }^{1}$. I sso permitiu a seus praticantes conceber seu objeto de estudo sob os termos de um contínuo social que abrangia desde as produções mais simples dos setores populares até a produção mais sofisticada das vanguardas artísticas contemporâneas.

Embora tenham sido muitos os projetos editoriais que ajudaram a consolidar e dar forma a essa corrente de interpretação do passado cultural latino-americano, o fato decisivo foi o aparecimento, em 1944, da coleção "Tierra Firme", sob o selo editorial da Fondo de Cultura Económica FCE. Essa editora, criada no M éxico em 1934 e fortalecida a partir da criação da C asa de España (mais tarde transformada em Colegio de M éxico) nesse país, que haveria de abrigar os intelectuais exilados após a derrota republicana na Guerra Civil espanhola, nascera com uma vocação americanista que se viu refletida na decisão de abrir pouco depois (1939) uma sucursal em Buenos Aires (que, além de empreender uma atividade editorial intensa, promoveria múltiplos eventos e reuniões intelectuais). A nova coleção, que vinha somar-se a outras que já haviam estabelecido o prestígio da FCE como editora de textos de economia e de sociologia (para dar um só exemplo, em 1944 foi publicada a primeira tradução em castelhano de Economia e sociedade, de $\mathrm{M}$ ax W eber), foi lançada por Arnaldo 0 rfila Reynal - editor argentino, militantesocialista eanimador cultural - eD aniel Cosío Villegas - historiador e editor mexicano, cuja obra principal, a $\mathrm{H}$ is toria moderna de M éxico, ainda estava por ser realizada - , e contou com 0 assessoramento informal de Alfonso Reyes, Pedro H enríquez U reña e outrosintelectuais latino-americanos. Concebida - ao menos no início - como um empreendimento muito ligado ao projeto, também americanista, de "C uadernos Americanos" (dirigidos por Alfonso Reyes eeditados pela FCE), "Tierra Firme" buscou integrar na lista de suas publicações todos aqueles estudos que enfocavam aspectos da cultura latino-americana, não impor- 
tando a disciplina a que pertencessem. D esse modo, além dos livros de temática histórica, engrossaram a lista textos de crítica literária, musicologia, geografia, demografia, antropologia e filosofia, sempre e quando o objeto de estudo tivesse a ver com algum aspecto da cultura latino-americana².

D entro desse complexo panorama, os títulos dedicados especificamente a explorar temas de história cultural constituíram o centro de gravidade da coleção em seu conjunto. Eles tenderam a dividir-se em duas categorias: os que analisavam aspectos ou o conjunto da história cultural de toda a América Latina, e os que restringiam seu enfoque a um único país (ainda queo pressuposto básico acerca da existência de uma história cultural compartilhada com os demais países da região quase nunca deixasse de estar presente). Pertencem à primeira categoria os dois livros que definiram com maior clareza o novo empreendimento historiográfico - D e la conquista a la independencia, do venezuelano M ariano Picón-Salas (1944), e H istoria de la cultura en la América hispánica, do dominicano Pedro H enríquez U reña (póstuma, 1947) - , aos quais deveriam ser somados dois ensaios de reflexão sobre a história cultural da região, Este pueblo de América, do coIombiano G ermán Arciniegas (1945), e ¿Existe América Latina?, do peruano Luis Alberto Sánchez (1945). N a segunda categoria registram-se al guns dos ensaios clássicos de interpretação da realidade nacional: Interpretação do Brasil, de Gilberto Freyre (1945, ano de sua primeira edição em qualquer idioma, inclusive o português), Letras de Nueva España, de Alfonso Reyes (1ª edição, 1946; 2ª edição "Tierra Firme", 1948), Raízes do Brasil, de Sérgio Buarque de H olanda (1954), Pinar del Río (1946) e Armonías y conflictos en torno a Cuba (1956), ambos do historiador e ensaísta cubano Emeterio S. Santovenia, e, entre outros títulos que poderiam ser mencionados, Ruta cultural del Perú (1944), do indianista e antropólogo peruano Luis E. Valcárcel. Finalmente, como uma subcategoria dentro dessa, deveriam ser contados os livros que fizeram parte da série "Las ideas políticas en...", entre os quais figuram dois que resultaram ser mais do que seu título prometia, pois elaboraram, por meio da análise do pensamento político, interpretações gerais de suas respectivas culturas nacionais: Las ideas políticas en Chile, do historiador Ricardo D onoso (1946), e Las ideas políticas en Argentina, de José Luis Romero (1946) - até então conhecido unicamente como medievalista. Apesar das inegáveis diferenças de enfoque e de registro temático que separam algumas dessas obras entre si, o efeito dessa vertiginosa somatória de publicações foi o de dar forma a um corpus ${ }^{3}$. É a partir dessa institucionalização editorial do projeto de uma
2. Sobrea renovação do campo editorial argentino nesse período, ver Sorá (2004) e N eiburg (2004).

3. Poderia ser incluído também nesse corpus, emboranão fizesse parte da coleção "Tierra Firme" nem fosse, em termos precisos, uma obra dehisória cultural, o notável ensaio etnográfico deO rtiz (1947). 0 pensamento de 0 rtiz foi de inquestionável importância para autores como Picón-Salas. 
análise histórica e cultural da região concebida como uma unidade que a história cultural latino-americana pôde cristalizar-se como uma corrente de interpretação com fisionomia própria.

As perspectivas ideológicas e de análise que deram forma a essa rica pletora de estudos da história cultural ibero-americana não só foram muito variadas entre si como também, no caso dos escritores de mais longa trajetória, implicaram um viés inconfundivelmente individual. Gilberto Freyre, Alfonso Reyes, M ariano Picón-Salas, Pedro H enríquez U reña, José Luis Romero, Sérgio Buarque de H olanda: cada um desses nomes chegou a ser, na década de 1940, quase uma marca, um selo, que servia para identificá-los como pensadores dotados de uma nítida personalidade intelectual. M esmo assim, no quadro desse projeto editorial e desse empreendimento cultural mais amplo, houve certa confluência entre os distintos olhares, que tendeu a produzir um objeto unitário. $\mathrm{N}$ as páginas que seguem será explorada apenas uma dessas interpretações da cultura iberoamericana, a que conseguiu condensar o projeto geral dessa história cultural da maneira mais completa esintética, integrando as distintas perspectivas parciais num grande afresco geral. Enquanto as importantes obras de Sérgio Buarque, de Gilberto Freyre ou de José Luis Romero circunscreviam seu campo de análise a um único país, enquanto a igualmente importante obra de Picón-Salas o circunscreveu num único período histórico - a época colonial - , o brevíssimo texto póstumo de $\mathrm{H}$ enríquez U reña, a H istoria de la cultura hi spánica (1947), abarcava todos os países da América Latina e toda a sua história, desde as civilizações pré-colombianas até o momento em que foi escrito. Esse livro (ao qual se pode somar sua outra grande síntese, traduzida também postumamente do inglês, Las corrientesliterarias en la América hispánica) traçava o esboço de todo o programa da nova história cultural latino-americanista.

Pedro H enríquez U reña elaborou uma obra entre 1905 e 1946 que se foi deslocando de seu interesse primigênio pela filosofia e a estética literária atéal cançar um novo centro na filologia e na história cultural. Elaborada em sua maior parte por meio de interpretações parciais e fragmentárias vertidas em ensaios de ocasião, resenhas, prólogos e discursos, seus livros, com raras exceções, consistiram sempre em recopilações de escritos. $M$ ais ainda, sua reflexão, embora ancorada numa perspectiva explicitamente americanista, nunca deixou de versar sobre um leque muito variado de temas: o pensamento social de Espinosa, o pragmatismo filosófico norteamericano, a mexicanidade de Juan Ruiz de Alarcón ou a pronúncia em 
São D omingos, para dar só alguns exemplos da amplitude temática de sua obra. No entanto ela tendeu a condensar-se em núcleos fortes que imprimem uma unidade geral a seu pensamento, sobretudo àquela porção que tratou da problemática da cultura ibero-americana e seu lugar no mundo.

Por um lado, a recuperação da tradição filosófica recusada pelo positivismo, esse retorno à metafísica tão proclamado nos distintos rincões da América hispânica nos anos de 1910, subjaz a seu discurso acerca de um novo humanismo. U ma posição filosófica marcada por um idealismo difuso quanto a suas doutrinas, mas preciso quanto à fronteira que traçava com 0 positivismo, manifestou-se em sua obra de diversas maneiras. Como para muitos outros intelectuais das primeiras décadas do século XX, a saída do marco positivista implicava uma reabilitação dos direitos da ética. Esse idealismo permitiu-Ihe, além disso, aderir a um conceito espiritualista da cultura - contrapartida da visão biologista e racial dos historiadores positivistas. Essa opção exerceu um papel decisivo na elaboração de sua imagem da cultura latino-americana: enquanto, para os historiadores positivistas, os distintos cruzamentos raciais efetuados nas diversas regiões da América Latina haviam implicado um continente dividido em grandes blocos raciais cujas potencialidades culturais diferiam marcadamente entre $\mathrm{si}, \mathrm{H}$ enríquez U reña pôde tomar como ponto de partida de toda a sua exploração histórica a concepção da unidade cultural dos latino-americanos.

Certo "arielismo"4 paira sobre quase toda a reflexão de Pedro H enríquez U reña acerca do lugar que deveria corresponder à América ibérica no concerto das civilizações mundiais. M as trata-se, no seu caso, de um arielismo radicalizado em dois sentidos. Primeiro, seguindo as pegadas de José Ingenieros, que em agosto de 1914 proclamara que o espetáculo bélico então iniciado não era senão "o suicídio dos bárbaros", H enríquez U reña desenvolveria ao longo de sua obra - quase toda ela produzida no período entre guerras - o tópico do "eclipse da Europa". D e acordo com o escritor dominicano, o colapso da civilização européia que a Primeira Guerra M undial e suas seqüelas pareciam augurar implicava para os latino-americanos uma oportunidade e uma obrigação. Livres da tutela cultural européia sob cuja égide haviam vivido seu primeiro século como nações independentes, os ibero-americanos poderiam agora aprender a pensar por si sós, a desenvolver seu próprio sistema de valores, seu próprio cenário estético, a dar expressão - com recursos que eles mesmos haviam elaborado - à sua própria realidade. $\mathrm{M}$ as, ao mesmo tempo, diante desse terrível desmoronamento do acervo artístico, literário e filosófico da maior riqueza que - segundo a
4. N ome genérico dado às doutrinas condensadaspelo crítico uruguaio José Enrique Rodó em seu célebre texto Ariel (1900). Essas doutrinas podem ser sintetizadas da seguinte maneira: uma revalorização da cultura latino-americana- comoterrado "espírito", representada por "Ariel" - diante da anglo-americana- terrado materialismo, representada por "Caliban"; uma análise que afirmava que esse caráter espiritual da América Latina estava ameaçado por um crescente filistinismo, sendo necessário portanto promover a criação de uma aristocraciado espírito; $\mathrm{e}$ finalmente, que ajuventude devia converter-se em portadoradessenovo humanismo espiritualizado. H enríquez U reña admirava esse ensaio e manteve certa correspondência com seu autor; Alfonso Reyes, por suaindicação, preparou a primeira edição mexicanado texto. 
5. Esse trecho do artigo foi omitido por ocasião de sua publicação em Seis ensayos en busca de nuestra expresión (1928). Ele foi reeditado pela primeira vez nas obras daBibliotecaAyacucho. Ver H enríquez U reña (1978, pp. 52-53). perspectiva deH enríquez U reña - o mundo presenciara, incumbia aos latino-americanos a tarefa de converter-se em guardiães espirituais do que havia de melhor nos valores e no pensamento da alta cultura européia. Em 1925, o importante artigo publicado na revista Valoraciones, de La Plata, "Caminos de nuestra historia literaria", havia condensado - com um tom interrogativo - essa concepção:

N ão sei se começaremos a "ser nós mesmos" amanhã ao amanhecer ou ao meiodia; não creio que a tarefa histórica da Europa esteja concluída, mas sim que, para nós, a Europa está em eclipse, perde o papel dogmático que exerceu durante cem anos. $\mathrm{N}$ ão é que tenhamos bússola própria; é que perdemos a al heia. [...] Voltará a Europa - lar da inquietude - à cômoda unidade de doutrinas oficiais como as de ontem? Voltaremos a ser alunos dóceis? O u alcançaremos - graças ao eclipse - a independência, a orientação livre? N ossa única esperança está em aprender a pensar as coisas desde a sua rai $z^{5}$.

A crise européia oferecia uma oportunidade, mas não garantia por si só a formação de uma civilização latino-americana em condições de medir-se com as demais civilizações do mundo. Somente se aprendessem "a pensar as coisas desde a sua raiz" é que os latino-americanos conseguiriam garantir a própria identidade, e somente conquistando a própria personalidade estariam em condições de preservar o melhor da cultura européia e produzir novas obras a partir dela.

A outra vertente desse "arielismo" radicalizado foi o discurso antiimperialista que deu forma a uma parte menor, mas nem por isso menos significativa, de sua obra. N uma data anterior à derrubada de seu pai do cargo de presidente da República D ominicana, H enríquez U reña começara a desenvolver uma pregação contra o expansionismo norte-americano no $\mathrm{C}$ aribe, que combinava tópicos tomados de ensaístas anteriores ou imediatamente posteriores à derrota espanhola de 1898 - H ostos, M artí, Varona - com uma reflexão movida pelo temor de uma intervenção anti-revolucionária por partedosE stados U nidosno M éxico. H enríquez U reña, assinando suas notas para EI H eraldo de Cuba com o pseudônimo de E. P. Garduño, interveio nos debates gerados pela ocupação norte-americana do porto de Veracruz em 1914, e por sua política expansionista no C aribe (que afetou, nos anos de 1910, sobretudo Cuba, São D omingos e H aiti). O rganizada em torno de dois núcleos discursivos inter-relacionados - o da incompreensão estadunidense da real idadelatino-americana eo do direito soberano das na- 
ções pequenas - , sua retórica antiimperialista coincidia com a parte central de sua obra, a reivindicação da existência de uma tradição cultural latinoamericana que, potencialmente, podia chegar algum dia a estar à altura da européia. Assim, em 1914, ele escrevera que, se a opinião pública norteamericana se inteirasse da produção cultural da região caribenha, "chegarse-ia a compreen der o queagora começa a seadivinhar sobretoda a América Latina: que não somos inferiores, mas diferentes, e que nossas inferioridades reais são explicáveis e corrigíveis, e que nossa personalidade internacional tem direito a afirmar-se como original e distinta" (H enríquez U reña, 1975, p. 18). Três anos mais tarde, como parte da campanha de toda a sua família para conseguir a reti rada das tropas norte-americanas de seu país, ele pronunciou uma conferência na Universidade de M innesota intitulada "Relações dos Estados U nidos e do C aribe", em cuja versão taquigráfica era sintetizada sua posição:

Ascolôniasnão têm espírito. [...] 0 spaísesindependentes eadoutrinaM onroe. [...] As queixas contra a doutrina são da América. [...] C rítica: as nações débeis não de vem ser tratadas por meio da força. [...] $\mathrm{N}$ ão deve haver mandado deforça por dívidas(D rago, C alvo), assim como não háparao indivíduo. 0 militarismo produzape nas males. $\mathrm{N}$ enhuma nação tem direito a pretender civilizar outra. Temoscerteza de que existem graus de civilização? 0 u existem tipos, classes de civilização? [...] M as estão civilizadostodos os Estados da U nião? Se pretendem civilizar o $\mathrm{H}$ aiti, por que não civilizar o estado de G eórgia? E quem decide qual país é civilizado equal não? Somentea força decideisso atéagora: ese a força devedecidir, não teríamos por que nos queixarmos daAlemanha: sua teoria era essa: como nação mais civilizada, devia civilizar o resto do mundo. Não há, pois, direito para querer civilizar outras nações. [...] Além disso uma colôniaé, como eu disse antes, uma coisa sem alma, sem alma própria: recebe seus modelos da metrópole. O s quenão viveram num pequeno país independente não conhecem o sentimento que existe neles de estarem elaborando sua própria vida, criando seu próprio tipo e modo de ser, criando constantemente. C ada nação pequenatem alma própria esenteisso. [...] 0 ideal da civilização não éa unificação completa detodos os homens edetodos os países, mas a conservação de todas as diferenças dentro de uma harmonia (2000, pp. 377-380).

N essas frases breves e entrecortadas aparece resumido não só todo o pensamento antiimperialista de $\mathrm{H}$ enríquez U reña; aparece claramente também a relação íntima que sua reflexão sobre a história cultural latino-americana mantinha com sua visão do lugar que essa cultura ocupava no mundo. 
O utro núcleo importante de seu pensamento consistiu na reflexão sobre a identidade cultural das formas de expressão literárias que se haviam desenvolvido na América Latina desde a época colonial. Seu discurso acerca dessa questão, deve-se enfatizar, recusava de um modo explícito o nacionalismo cultural: ante aqueles que insistiam que o eclipse europeu implicava a necessidade de rechaçar toda a tradição cultural européia, $H$ enríquez U reña postularia que isso era impossível, dado que a própria cultura latino-americana possuía raiz européia, ao menos quanto a suas expressões letradas. Essa região cultural pertencia por suas línguas (literárias) ao tronco ibérico e, por meio dele, ao tronco maior de todas as línguas herdadas do latim, a România dos lingüistas. Entre a cultura do M editerrâneo e a das nações latinoamericanas havia uma continuidadeimpossível de abandonar: rechaçar essa herança equivaleria a uma mutilação auto-infligida. É por isso que, para conquistar a própria personalidade literária, artística ou filosófica, era ne cessário primeiro reapropriar-se do melhor da tradição cultural espanhola (e, no caso do Brasil, portuguesa). Ressignificada a partir de sua leitura de um ponto devista latino-americano, essa tradição permitiria aos escritorese intelectuais do continente garantir sua própria identidade, evitando os dois perigos que espreitavam respectivamente os nacional istas culturais e os defensores a todo transe da europeização cultural: 0 encerramento e o empobrecimento da própria herança cultural, por um lado, eo aniquilamento da própria identidade, por outro. A língua, casa do ser, era, para $\mathrm{H}$ enríquez U reña, a matriz por meio da qual deveriam se moldar todas as atividades intelectuais eartísticas: no caso dos latino-americanos, ela não podia ser outra senão - já que não existiam ainda línguas indígenas escritas dotadas de uma prestigiosa tradição literária - o espanhol ou o português. No entanto, embora a língua fosse européia, o fundo cultural dos latino-americanos não o era (cf. H enríquez U reña, 1928, p. 29). A experiência de vida nesse continente, tão distinto da Europa, a herança cultural indígena ou africana e a pequena tradição crioula de expressão literária emusical - demenos de dois séculos de duração - conformavam uma "energia nativa" subjacente e modeladora de qualquer meio de expressão que se utilizasse. 0 espírito da cultura latino-americana era nativo (cf. I dem, p. 31).

A reflexão acerca da língua literária e dos modos mais adequados de dar expressão à autêntica experiência nacional e latino-americana prosseguia de um modo direto num quarto núcleo organizador de seu pensamento, a reflexão sobre os padrões lingüísticos do continente e o trabal ho - elaborado a partir da mesma - de classificação dialetológica. H enríquez U reña 
defenderia, em toda uma série de trabalhos monográficos produzidos no quadro de sua inserção no Instituto de Filologia, a casticidade dos idiomas espanhol e português falados na América. Em vez de línguas híbridas ou de grande incorporação de formas gramaticais indígenas ou africanas - e em claro contraste com o "papiamento" (língua crioula das Antilhas holandesas) e outros linguajares créoles falados nas ilhas antil hanas -, o espanhol e o português eram, segundo seu argumento, "línguas normais". As diferenças entre a fala dos americanos e a dos habitantes de Portugal e Espanha consistiam em variantes introduzidas por opções léxicas e gramaticais feitas sobre o grande acervo histórico dessas línguas em sua longa evolução: dito de outro modo, onde muitos lingüistas acreditavam ver empréstimos das línguas indígenas ou africanas, H enríquez U reña via como fonte da variação da fala em cada região - arcaísmos ou opções dialetais. Por exemplo, no caso do castelhano falado em São Domingos, ele sustentou que não havia nenhuma influência lingüística de origem africana e praticamente nenhuma de origem indígena. As formas idiossincráticas de pronúncia podiam ser explicadas pela história do castelhano e respondiam a modelos arcaicos da fala; e os elementos lexicais, que outros lingüistas e etnógrafos (entre eles Alfred M étraux) acreditavam derivados do contato com as línguas faladas pelos escravos africanos, seriam provenientes de fontes indígenas, de usos arcaicos do castelhano, ou consistiriam em meros localismos evoluídos a partir do castelhano original. Essas conclusões não expressavam nenhuma opção ideológica explicitamente antiafricanista ou antiindigenista: noutras partes de sua obra percebe-se um grande apreço pela contribuição cultural dos povos dessas procedências étnicas. Todas as suas conclusões se baseavam em investigações empíricas de grande envergadura, e numa análise que se atinha aos parâmetros do que naqueles anos eram considerados os protocolos de investigação normais e legítimos dentro da disciplina filológica. Ao mesmo tempo, tudo parece indicar que nessa insistência sobre a pureza do castelhano operava também por meio dos próprios protocolos de investigação, e não fora deles - a dissimetria de perspectivas que os habitus constituídos produzem no itinerário pelo espaço social, uma dissimetria que, no caso dele, não Ihe permitia ver as marcas do africano nos materiais lingüísticos que examinava, muito embora, a exemplo de Freyre e outros, aceitasse sua existência em outras ordens do cultural, como as comidas e seu preparo ${ }^{6}$.

Todos esses trabal hos realizados no quadro de diferentes disciplinas e gêneros de escrita desembocaram, finalmente, em meados dos anos de
6. “[...] tenho o hábito de citar, deformando um pouco, umafórmula célebre de Pascal: '0 mundo me compreende e me absorve como um ponto, mas eu 0 compreendo'. 0 espaço social me engloba como um ponto. Mas esse ponto é um ponto de vista, o princípio de uma visão tomada a partir de um ponto situado no espaço social, de uma perspectiva definida em sua forma e em seu conteúdo pela posição objetiva a partir da qual étomada. 0 espaço social é de fato a realidade primeira $\mathrm{e}$ última, já que comanda também as representações que os agentes sociais podem ter dele" (Bourdieu, 1994, pp. 28-29). 
1940, no seu volume para a coleção "Tierra Firme", que pretendia ser uma síntese geral da história cultural da região. De alcance mais ambicioso que o curso de conferências que dera origem a Literary currents in $\mathrm{H}$ ispanic America, a H istoria de la cultura en la América H ispánica (1947) buscava ser uma interpretação geral do desenvolvimento cultural ibero-americano. É possível assinalar a existência de três características fundamentais que serviram para definir o projeto intelectual expresso em suas páginas: a vontade integradora que preside à definição do objeto, o propósito enciclopedista que dá forma a seus argumentos e a concisão precisa dos mesmos. $D$ iferentemente de suas conferências em $\mathrm{H}$ arvard, nas quais seu campo de visão abrangera apenas a produção literária, no livro em questão o termo "cultura" designava simultaneamente a atividade humana em seu conjunto (as formas de moradia e de assentamento, as comidas, os rituais, os métodos de agricultura, a legislação, as formas políticas etc.) e a produção cultural especializada (artes, ciências, letras): a relação de continuidade entre ambas era o postulado implícito sobre cuja base se desenvolvia a análise. Essa vontade integradora operava também na definição dos espaços histórico e geográfico que o estudo devia abranger. No tempo, a história da América hispânica se estendia até abarcar as civilizações e povos précolombianos. Apenas dois anos antes, em seu prólogo ao livro de $M$ ariano Picón-Salas, D e la conquista a la independencia, H enríquez U reña havia declarado que o que antes era denominado "o passado indígena", como se não existisse nenhuma continuidade entre as culturas posteriores à conquista e as anteriores, devia ser chamado daí em diante de "o legado indígena" - um legado que perdurava nas formas mais simples e ubíquas do viver, mesmo quando a arquitetura e as religiões indígenas houvessem sido inteiramente extirpadas. No espaço, essa vontade integradora incorporava o Brasil de um modo contundente ao conjunto dos países "hispânicos". Rebentos de um tronco comum, segundo a interpretação de $\mathrm{H}$ enríquez U reña, a diferença de línguas havia operado menos como uma fronteira fechada do que como um espaço de intercâmbios mútuos. N essa visão, a cultura de língua portuguesa e a de língua espanhola teriam interagido entre si, de um modo quase dialético, ao longo de sua história:

A história da cultura portuguesa está ligada à da cultura espanhola; na literatura houve influências mútuas; assim como nos séculos XII e XIII era comum que os castel hanos compusessem cantares em português, no XVI eno XVII os portugueses escreveram muito em castelhano, tanto em verso como em prosa (U reña, 1947). 
U ma palavra-chave presidia a todas essas operações integradoras: "fusão". Como conseqüência de sua recepção entusiástica das contribuições de Picón-Salas, de G ilberto Freyre, de Germán Arciniegas e de antropólogos como Robert Redfield, parecia agora evidente, para H enríquez U reña, que a cultura dos americanos "hispânicos" não era o resultado de um mero transplante, como antes acreditara: ela derivava de uma fusão de culturas. Toda a história cultural da América hispânica teria consistido num vasto processo de "transculturação". D essa perspectiva, tornava-se impossível compreender os processos de transformação que haviam produzido os sucessivos estilos, modas e tendências na produção cultural especializada, se esta não fosse cotejada com todos os demais fenômenos que faziam parte da vida dos latino-americanos.

Em síntese, o livro de U reña oferecia uma interpretação geral da história cultural da América hispânica. Essa história consistia num processo de transculturação - produto da conquista dos povos indígenas e da importação de escravos africanos - que teria originado a "situação complexa" dos produtores culturais nas Américas. Para esses habitantes de sociedades nas quais avançava rapidamente a democracia social, em que desapareciam os últimos vestígios dos preconceitos raciais herdados da época colonial e em que as mesmas forças modernizadoras que faziam sentir seu impacto noutras partes do globo produziam resultados inesperados e às vezes paradoxais, a conquista da própria expressão, a elaboração de um estilo cultural próprio e com uma identidade definida, apresentava-se como uma possibilidade necessária. M uito consciente desse caráter paradoxal e incerto de uma cultura em que barracos e casebres coexistiam com as torres modernas, e de um continente no qual alguns - os mexicanos e os peruanos, no seu entender - avançavam rumo à "redenção do índio", enquanto outrosos brasileiros e os argentinos - retrocediam a formas políticas arcaicas em conseqüência da implantação das novas ditaduras, o conceito de cultura que anima os últimos livros de $\mathrm{H}$ enríquez U reña - e sobretudo o H istoria de la cultura - coincidia plenamente com a seguinte descrição (referida ao âmbito cubano) do historiador cultural eetnólogo cubano Fernando 0 rtiz, cuja obra U reña havia citado elogiosamente:

[...] mas qual éa cultura característica de Cuba? Para sabê-lo seria preciso estudar um complexo muito intrincado de elementos emocionais, intelectuais e volitivos. $\mathrm{N}$ ão só nas manifestações das individual idades destacadas na vida cubana pela relevância de suas personalidades, mas também em todas as sedimentaç̃oes, nos picos 
7. U ma posição similar é a amplamente desenvolvida por Randall Collins (1998, p. 37). Além deaplicar um quadro teórico elaborado a partir do (ou pelo menosmuito marcado pelo) instrumento conceitual cunhado por Bourdieu, mastraduzido numalinguagem fortemente "goffmaniana', elefaza observação pertinente(embora difícil de perceber na prática) de que o estudo das redes regionais ou articuladas num circuito de "rituais de interação" devem ser entendidassempreno contexto da totalidade das redes que compõem 0 universo intelectual global em qualquer momento histórico dado. $\mathrm{N}$ ão só por razões deespaço, essa totalidadedeverá ser entendida neste texto de um modo "virtual". das montanhas, nas encostas, nos vales, nas planícies e até nos pântanos. Toda cultura é essencialmente um fato social. N ão só nos planos da vida atual, mas nos de seu advento histórico e de seu devir previsível. Toda cultura é dinâmica. E não só em seu transplante desde múltiplos ambientes estranhos ao singular de Cuba, mas em suas transformações locais. Toda cultura é criadora: toda cultura é criadora, dinâmica e social (O rtiz, 1949).

É difícil supor que esta não tenha sido a definição que presidiu à história cultural elaborada pelo filólogo dominicano.

D e fato, esse momento de cristalização da nova história cultural, representado não apenas pelo livro emblemático de H enríquez U reña, mas pelos outros títulos mencionados, não surgiu unicamente por iniciativa de um empreendimento editorial: para que fosse possível essa eclosão de obras e interpretações mais ou menos aparentadas entre si, foi preciso uma longa etapa de preparação prévia. Sem uma lenta etenaz acumulação dos recursos culturais e disciplinares necessários para produzir um discurso historiográfico habilitado a reinterpretar a identidade regional da América Latina e 0 passado que lhe deu origem, a iniciativa da FCE não teria produzido mais que uma série de títulos rotineiros e sem maior valor intelectual. Essa acumulação préviafora feita em vários dos principais países da região - M éxico, Brasil, Peru, Argentina, Cuba - etambém nas antigas metrópoles, sobretudo na Espanha. No entanto, a intensa atividade de ensaístas, historiadorese críticos, que logo serviu de insumo e suporte a essa nova história cultural, ocorreu muitas vezes de um modo isolado, al heio às reflexões eà investigação que se estavam produzindo noutras nações latino-americanas. É por esse motivo que a constituição progressiva de distintas redes culturais cada vez mais cruzadas entre si - foi decisiva para que se criassem as condições de possi bilidade desse empreendimento cultural. Sem a circulação de saberes, sem a troca de olhares e de experiências que essas redes de indivíduos e grupos permitiram, não teria sido possível a emergência de uma perspectiva histórico-cultural compartilhada ou pelo menos convergente, e muito menos a constituição de uma formação cultural ligada por uma estrutura de sentimento compartilhada7. A seguir serão examinadas duas instâncias cruciais na formação desse conjunto de redes culturais entrecruzadas: primeiro, a dos intelectuais mexicanos do centenário e da Revolução, cujas redes grupais se constituíram sobrea base da experiência compartilhada na Sociedad de Conferencias (1906-1909), no A teneo de la Juventud (1909-1914), na criação da Universidade N acional do M éxico (1910- 
1929) e na própria Revolução M exicana; segundo, a da expansão dessas redes para os principais centros culturais ibero-americanos, cujos protagonistas principais foram José Vasconcelos - como precursor -, Pedro H enríquez U reña e Alfonso Reyes.

Entre os "cientistas" e a Revolução: o campo intelectual mexicano e a condensação de uma estrutura de sentimento grupal e geracional, 1906-19248

O M éxico foi o crisol onde se articulou pela primeira vez, por meio do estabelecimento de um temário de inquietudes e insatisfações compartiIhadas e de uma prolongada experiência comum em diversos empreendimentos grupais, um esboço do programa de estudo e reflexão que permitiria criar, ao cabo de várias décadas, as condições para que se conden sasse como objeto de investigação histórica - uma visão unitária da cultura latino-americana. 0 programa original - aquele identificado com a formação cultural integrada pelos membros da "geração do Centenário" e do movimento A teneísta - nasceu como resposta às condições específicas do campo intelectual mexicano durante a última década do "Porfiriato", o governo ditatorial de Porfírio D íaz (cf. C osío Villegas, 1963-1972; Knight, 1986). A trajetória que conduziu de uma remota origem asteca a uma série de confluências com outros campos intelectuais ibero-americanos, até produzir a galáxia de circuitos transnacionais de intercâmbio cultural da qual emergi ria o projeto "T ierra Firme" da FCE, correspondeu aos deslocamentos geográficos e à simultânea construção de uma ampla rede epistolar e de intercâmbios acadêmicos por parte de três dos membros do círculo "ateneísta": 0 itinerário precursor de José Vasconcelos - 0 autodenominado "U lisses crioulo" -, que abriu o caminho para os que o seguiram, e os itine rários também decisivos de Pedro H enríquez U reña e Alfonso Reyes. M ais ainda: se a versão do programa "ateneísta", do qual esses três intelectuais foram portadores, encontrou certa predisposição em al guns setores dos outros campos intelectuais da região - sobretudo em M adri e Buenos Aires, mas também, de um modo mais marginal, em São Paulo, Rio de Janeiro, $\mathrm{H}$ avana, $\mathrm{C}$ aracas e Lima (para mencionar apenas os centros intelectuais de maior importância) - , isso se deve a que no interior desses campos se haviam produzido deslocamentos homólogos ao protagonizado pelo grupo mexicano.

$N$ os começos do século XX, o campo intelectual mexicano continuava sob a férrea dominação da escola positivista que na década de 1860 - sob
8. É vastaaliteraturahis tóricasobreesseperíodo, que coincide com a Revolução M exicana. Sobre a Revolução, ver Knight (1986), Womack (1969), Katz (1998), Vários (1974-1981). Sobre a históriaintelectual do pe ríodo, ver Krause(1985), Villegas (1993), M onsiváis (1976). Sobre a relação entreo ensaio deinterpretação nacional e o espaço cultural mexicano, ver o excelenteestudo de Lomnitz-Adler (1992). 
9. Essa situação não se modificaria com a Re volução (muito pelo contrário), nem até, pelo menos, osanos de 1980 e 1990.

10.0 s outros intelectuais positivistas que ocupavam posiç̧es dominantesno campo intelectual mexicano entre 1900 e 1911 eram Porfirio Parra (18551912), Ezequiel Chávez, Andrés Enríquez M olina- cujo livro Losgrandesproblemasnacionales converteu-se num ma nual programático de várias das facções revolucionárias -, Federico Gamboa, Emilio Rabasa (1856-1930) - todos eles associados ao grupo dos "cientistas" - e Francisco Bulnes - ensaísta conservador e franco-atirador intelectual. Ver Zea (1968) e Schmidt (1978).

11. Segundo o Censo Nacional de 1910, de uma população total de 15.160.369 pessoas, apenasum quinto eraalfabetizada, ou seja, 2.992.026. o impulso de Gabino Barreda - havia oferecido aos líderes da "República Restaurada" (1867-1876) uma matriz filosófica de extrema utilidade, num momento em que se buscava deslocar dos principais espaços de poder os setores católicos mais conservadores. Três características fundamentais definiam então esse campo: a) seu nível muito baixo de autonomia, corolário de sua clara subordinação ao poder polític $0^{9}$; b) a estreita relação de dependência (como na maior parte dos países latino-americanos da época) entre a posição social e a posição ocupada no campo intelectual - não só quase todos os que eram admitidos nesse campo provinham das camadas mais altas da elite mexicana, mas também, como regra geral, o capital social mais que o simbólico - continuava sendo o elemento determinante, ao longo de toda a trajetória dos intelectuais, da posição ocupada no seu interior; c) seu baixo nível de institucionalização. 0 fato de que Justo Sierra secretário de Instrução Pública e Belas Artes de Porfirio Díaz, historiador colocado no topo de sua disciplina e chefe (como sucessor de $G$ abino Barreda, após sua morte em 1881) do movimento positivista mexicano - tenha podido exercer durante décadas o papel incontestado de dispensador supremo de legitimidade a toda iniciativa nova no interior do campo intelectual, admitindo e expulsando autocraticamente seus novos e antigos habitantes, exprime de forma resumida essas três características. Até 1911, o campo intelectual mexicano funcionou como um "porfiriato dos bens simbólicos", em cujo interior Sierra era - por certo mais benévolo que o original - seu Porfirio Díaz ${ }^{10}$.

Tanto em termos geográficos como sociais, tratava-se de um campo intelectual altamente concentrado: não só emergia do pequeníssimo universo de pessoas alfabetizadas que existia então no M éxico, como estava em grande parte confinado à Cidade do M éxico e, ali, às poucas instituições que na época ofereciam uma educação superior ${ }^{11}$. C onseqüência direta do impacto da filosofia positivista, não havia nenhuma universidade no M éxico, apenas um conjunto de escolas de educação superior independentes, que ofereciam os títulos correspondentes às principais disciplinas: jurisprudência, medicina, agricultura e veterinária, engenharia, belas-artes, comércio e administração, artes e ofícios. Também havia, como preâmbulo ao ingresso em quase todas essas escolas superiores, uma "Escuela $\mathrm{Na-}$ cional Preparatoria" - de todas, a de maior prestígio intelectual - que, na Cidade do M éxico, se encarregava da educação secundária dos filhos da elite. D escentralizadas e sem maior prestígio cultural, as demais escolas de educação superior desempenharam um papel muito pequeno na vida inte- 
lectual mexicana durante o Porfiriato, situação que tendeu a reforçar a relação entre o campo intelectual local e o poder político.

Foi nesse quadro que a geração que atingiu a maioridade entre $1900 \mathrm{e}$ 1910 começou a promover uma série de iniciativas culturais, cujo propósito central era renovar 0 ambiente intelectual mexicano. Esse programa de renovação estava condensado - qual símbolo totêmico detodo o grupo - na proposta antipositivista de "restauração da filosofia". É fundamental, para uma adequada compreensão do processo pelo qual começou a reorganização do campo cultural no M éxico, sublinhar que os jovens intelectuais que posteriormente foram batizados com o nome coletivo de "ateneístas" não eram, no período em questão, mais do queisso: jovens. 0 cupavam, portanto, um lugar subordinado emarginal dentro do rudimentar campo cultural hegemonizado pela geração dos "cientistas". Como observou com razão C arlos M onsiváis, esses jovens, em vez de formarem uma vanguarda empenhada numa ruptura ruidosa com o establishment cultural, eram como um conjunto de discípulos bem-dotados e estudiosos que, sem romper formalmente com seus superiores - como demonstra sua relação de colaboração estreita com J usto Sierra - , buscou consolidar as condições de possibilidade para uma futura trajetória exitosa tanto do grupo "geracional" como dos diferentes indivíduos que o integravam. As diferenças de orientação intelectual que serviram para distinguir a maioria dos membros desse grupo de seus superiores foram pouco estridentes expressaram-sequase sempre- ao menos na etapa anterior ao clima de transgressão inaugurado pela Revolução - em termos matizados e muitas vezes cordiais. $\mathrm{N}$ as palavras de M onsiváís:

\footnotetext{
De algum modo, os mais entusiastas entre os "ateneístas" esperam sua subida pessoal ao poder [...]. Segundo seu ponto de vista, o porfirismo não só liquidou 0 cultivo das humanidades, mas tirou-lhes o lugar e o sentido. Eles se consideram preteridos ou freados em seu direito de agir. Pertencem a uma camada social desesperada não diante do panorama de injustiça e miséria, mas diante da eternidade declarada do regime de Díaz. São, em seu egoísmo de classe, sinceros e diáfanos (M onsiváis, 1976).
}

O s principais traços que ajudaram a definir o programa de renovação promovido por essegrupo foram os seguintes: 1) um crescente desassossego ante a filosofia positivista, que se expressou - de um modo diferenciado conformeos diversos autores e conferencistas - numa recuperação entusiás- 
tica da filosofia platônica, numa referência explícita a N ietzsche, numa abertura progressiva às três novas correntes filosóficas que podiam ser vislumbradas desde o mirante que era o M éxico às vésperas da Revolução (o pragmatismo americano, o neokantismo alemão e o bergsonismo francês) ou - éo caso de José Vasconcelos - num espiritualismo "hindustânico"; 2) um neo-helenismo difuso - parte de um clima cultural permeado pela recente recep ção de $\mathrm{N}$ ietzschee, demaneira mais geral, pela virada helenizante que o "modernismo" literário contribuíra a aclimatar - que se manifestava nas leituras e nas alcunhas que os membros dessa geração se aplicavam a si mesmos - Vasconcelos seria "U lisses", H enríquez U reña, "Sócrates" ou "El D orio", Alfonso Reyes, "Euforión", entre muitos outros; 3) uma crescente preocupação pelo nacional mexicano - evidenciado nas discussões acerca das formas musicais e pictóricas autóctones e seu possível uso como base de uma arte "nacional", não européia, que em poucos anosia adquirir um traço marcadamente antiimperialista -, sobretudo no caso dos "ateneístas" convertidos em porta-vozes e intérpretes da Revolução, ou daqueles, como H enríquez U reña, diretamente afetados pelo expansionismo norte americano da época; 4) uma ruptura estética com as correntes classicistas e românticas (que no M éxico ainda possuíam um prestígio cultural considerável) mediante uma entusiástica adesão à poesia "modernista", seguida de uma recusa que assumiu várias formas e cujos atributos centrais foram a insistência no dever social da literatura e num estilo mais sóbrio e contido; em matéria estética, essa posição ocupava, pode-se dizer, a estreita e ambígua faixa constituída pelo "pós-modernismo" e o "pré-vanguardismo"; 5) uma difusa ênfasena natureza cultural das identidades sociais (o que implicava uma ruptura com o positivismo também nesse ponto, mediante a recusa da noção biologista de "raça") ea recuperação do "cultural" como legítimo objeto de estudo; 6) a articulação de um projeto de progressiva institucionalização do campo cultural, sobretudo em relação à educação superior; e 7) no caso de uma minoria de seus membros, uma vocação explicitamente ibero-americanista. Esse projeto geracional ecultural se impôs- e, no processo, definiu-se a si mesmo - por uma série de empreendimentos culturais coletivos promovidos durante a década de 1900.

O s dois primeiros passos nesse itinerário geracional, que serviram para dar uma coesão de grupo ao núcleo central do movimento, foram a publicação da revista juvenil Savia M oderna (1906-1907) - faziam parte da equipe de redatores Alfonso C ravioto, promotor e diretor, Antonio C aso e Pedro H enríquez Ureña - e a Sociedad de Conferencias (1906-1909) - 
concebida pelo malogrado arquiteto Jesús T. Acevedo, que de início soube ser um dos personagens centrais desse movimento juvenil ${ }^{12}$. No âmbito dessa sociedade, cujos condutores intelectuais foram Antonio C aso ePedro H enríquez U reña, desenvolveram-se duas atividades centrais: um programa de estudos informais para atualizar os conhecimentos filosóficos, históricos e literários de seus membros - o plano de leituras foi preparado por U reña e C aso - , e uma série de conferências públicas sobre temas culturais muito díspares, que abrangiam desde as últimas novidades musicais e arquitetônicas até esboços biográficos de importantes intelectuais latinoamericanos do passado recente. Em 1906, H enríquez U reña descreveu os trabalhos dessa Sociedad da seguinte maneira:

Um efforço consciente, um labor de estudo, uma manifestação de personalidade: isso foi a série inaugural de conferências, primícias de um vasto projeto, organizado pelo grupo mais seleto da juventudeintelectual mexicana, constituído na Sociedad, e celebradas nos meses de maio a agosto (1910, pp. 291-297).

A temática das conferências foi extremamente eclética, reflexo fiel das distintas formações disciplinares de seus integrantes e de certa imaturidade geral do projeto cultural que elas deviam comunicar ao público. A primeira ea segunda séries de conferências consistiram em: (1a) "A obra pictórica de Carrière", por Alfonso Cravioto; "Nietzsche", por Antonio Caso; "A evolução da crítica", por Rúben Valenti; "Aspectos da arquitetura doméstica”, por Jesús T. Acevedo; "Edgar Poe", por Ricardo Gómez Robelo; e "Gabriel y Galán", por Pedro Henríquez U reña; (2aㅡ "M ax Stirner", por Antonio Caso; "A influência de Chopin na música moderna", por M ax H enríquez U reña; "D 'Annunzio", por Jenaro Fernández MacGregor; e "Pereda", por Isidro Fabela. Foi finalmente sobre a base dessa primeira experiência grupal que Antonio C aso - com a concordância tácita de Justo Sierra - tomou a iniciativa de lançar o A teneo de la Juventud, uma versão ampliada (e mais pública) da Sociedad de Conferencias, que acabaria convertendo-se, após a queda de Porfirio D íaz, no Ateneo de M éxico, presidido por José Vasconcelos. Esse sucedâneo continuou com suas sessões semanais até extinguir-se em meio ao caos que acompanhou a etapa mais sombria da Revolução - com a crise iniciada pela rebelião de Victoriano H uerta em 1913 e o começo da guerra civil entre diversos exércitos rivais.

$\mathrm{Na}$ evolução do Ateneo podem-se vislumbrar algumas das diversas opções que definiram os itinerários alternativos de seus integrantes. Se na ori-
12. “N o grupo literário de Savia M oderna havia dois tipos de escritores: osque escrevem, os que não escrevem. Entre os segundos, e o primeiro de todos, Acevedo. Ele dizia, com Goethe, que escrever é um abuso da palavra. M aistarde incorreu na letra escrita. Conversador incomparável, conferencista claro e justo. 0 nome de Jesús Acevedo figura em nossos livros, mas sua obra, que foi sobretudo a de precursor, obra deconversas, conjeturas, promessas, não poderá ser compilada" (Reyes, 1962, p. 204). 
gem elenascera como expressão do projeto de renovação cultural compartiIhado por C aso e Henríquez U reña (aquele foi o primeiro presidente do Ateneo, este, seu primeiro "secretário"), a defesa que o segundo fazia de uma posição explicitamente antipositivista levou a uma progressiva cisão entre os dois. Enquanto C aso preferia abordar a história do positivismo em termos elogiosos, cal culados para não irritar as figuras mais poderosas do universo cultural mexicano - e isso em clara contradição com suas convicções pessoais acerca desse movimento filosófico - , H enríquez U reña queria efe tuar um rompimento categórico. A primeira conferência sobre o positivismo pronunciada por $C$ aso Ihevaleu, assim, uma dura crítica da parte do dominicano, que julgou ver nela uma abdicação da vontade de ruptura do cenáculo que eles integravam. $\mathrm{N}$ um retrato de $\mathrm{C}$ aso publicado em seu segundo livro, H oras de estudio, U reña o descreveu do seguinte modo:

0 conferencista é muito jovem, acaba de transpor o limite dos 25 anos; pode ser que viaje, pode ser que modifique suas idéias, pode ser que siga novos métodos, novos rumos... A personalidade que ele mostra atualmente deve evoluir. Pode ser também (não o desejamos) que se detenha onde começou, que se deixe vencer pela inércia que na América espanhola (e particularmente no $M$ éxico) leva todas as coisas ao estancamento rápido [...]. Costuma sentir temores e, por respeito à autoridade, aceitar sem discussão uma idéia, ou, por medo de destruir, esquivar a análise (como fez ao falar de Comte); mas, quando se sentefirme, percorre com segura agilidade os problemas e as séries históricas (1910b, pp. 57-59).

O s demais "ateneístas" - com a parcial exceção de Reyes e Vasconcelosparecem ter preferido em sua maior parte uma ruptura mais suave com 0 positivismo de seus superiores.

0 Ateneo de la Juventud conseguiu impor-se muito rapidamente como uma das instituições centrais dentro do campo intelectual mexicano, consagrando seus membros, desse modo, como a futura geração de relevo. Em 1909, por exemplo, dos 32 membros residentes no M éxico (havia oito membros correspondentes no exterior, entre eles $M$ ax, 0 irmão de Pedro H enríquez U reña, e o pintor D iego Rivera), quatro eram deputados no Congresso $\mathrm{N}$ acional, um era secretário do $\mathrm{M}$ useu $\mathrm{N}$ acional e outro era subdiretor da Escola $\mathrm{N}$ acional Preparatória. A repercussão das sessões chegou - em parte graças à atividade propagandística de Pedro e seu irmão M ax (em Cuba) - a projetar vários de seus membros como intelectuais de nível continental: H enríquez U reña estabeleceu relações epistolares com 
figuras latino-americanas de posição consolidada, como José Enrique Rodó, M anuel U garte, Rufino Blanco-Fombona eFrancisco G arcía Calderón, enquanto Reyes criou vínculos com os meios intelectuais cubanos. Em 1910, aproveitando a ampla cobertura jornalística recebida em Cuba, M ax U reña e J esús C astellanos fundaram em $\mathrm{H}$ avana uma versão cubana da Sociedad de Conferenciais. E mais: a então prestigiosa editora O llendorf abria-se a suas publicações, colocando assim a obra da Sociedad numa vitrine de al cance continental (Pedro H enríquez U reña pôde publicar por essa editora graças a uma gestão de $\mathrm{G}$ arcía C alderón, e também Reyes, graças a igual favor de Pedro; em 1914, este último devolveria o favor a García Calderón, fazendo publicar um livro de seu irmão menor, Ventura, embora admitisse privadamente que carecia por completo de qualidade literária). Ao mesmo tempo que crescia a projeção internacional dessa incipiente formação cultural, seus membros passavam a exercer um papel central nas novas instituições acadêmicas promovidas pelo governo mexicano.

Entre 1910 e 1930, as principais instituições relacionadas ao âmbito educativo atestariam a crescente - embora flutuante - presença do núcleo central dos "ateneístas". A decisão tomada por Justo Sierra de fundar a U niversidade N acional do M éxico em 1910 ofereceu-Ihes uma inserção institucional mais prestigiosa e estável, com a oportunidade de desempenhar um papel ativo na elaboração da nova cultura universitária do país. Em seus primeiros anos, a universidade consistiu numa simples reunificação de todas as antigas Escolas Superiores. Para ocupar o centro da universidade foi criada uma nova Escola Superior, a de Altos Estudos. Posta a princípio sob a égide daqueles professores que pertenciam, segundo Pedro $\mathrm{H}$ enríquez U reña, ao "antigo regime", a presença de C aso como catedrático (desde 1909 ele era professor de sociologia na Escola $\mathrm{N}$ acional de Jurisprudência e, quando esta foi incorporada como faculdade à nova U niversidade $\mathrm{N}$ acional, seguiu mantendo o cargo, mais o de "secretário da U niversidade $\mathrm{Na-}$ cional") serviu como uma espécie de ponta-de-lança de todo o grupo. Acrescentando em seguida uma cátedra de filosofia a seu currículo docente, C aso, sem enfrentar muito explicitamente os sucessivos governos revolucionários, pôde articular aos poucos uma série de al ianças com outros setores daquela instituição que prepararam 0 ambiente para o revezamento geracional que finalmente se consumou com a nomeação de José Vasconcelos como reitor em 1920. 0 começo desse revezamento se deu com a mudança de autoridade provocada pela chegada dos "huertistas" ao poder nacional em $1913^{13}$. O novo diretor da Escola de Altos Estudos, Ezequiel
13. 0 partido queapoia va Victoriano Huerta (1913-1914). Responsável peladerrubadaemorte do iniciador da Revolução M exicana, Francis co M adero (1911-1913), sua brevepresidência foi considerada de natureza "contra-revolucionária" pela historiografia mexicana. N os últimos anos começou umarevisão do papel do "huertismo". 
Chávez (antigo "cientista"), procedeu à criação de uma Faculdade de H umanidades - mesmo sem apoio orçamentário do Estado, sintoma evidente de sua marginalidade. Ali iniciaram sua carreira docente na Universidade Nacional vários dos "ateneístas": Pedro H enríquez U reña lecionou literatura inglesa, Reyes, língua e literatura espanholas, e C aso, estética. M as 0 projeto naufragou. A nova volta do parafuso da disputa revolucionária - a queda de H uerta ea subida ao poder deVenustiano C arranza (1914-1920) arruinou completamente esse primeiro esforço por incorporar as disciplinas "humanistas" ao currículo universitário: a faculdade foi dissolvida e três de seus principais animadores, Pedro U reña - por decisão própria - , Alfonso Reyes - por força das circunstâncias - e José Vasconcelos - por ter mudado de lado num momento pouco oportuno - , se viram impelidos a tomar o caminho do exílio.

0 triunfo decisivo dos "atenéstas" (acompanhados em sua ascensão pelo grupo levemente mais jovem da Geração de 1915) ocorreu em conseqüência da vitória do chamado grupo Sonorense de revolucionários mexicanos (cf. Aguillar Camín, 1977); a derrota de Venustiano Carranza pelos líderes da revolta de Agua Prieta - Álvaro O bregón (de 1920 a 1924, e 1928), Plutarco Elías Calles (de 1924 a 1928, chefe supremo de 1928 a 1935) e Adolfo de la H uerta (1911 e 1924) - conduziu alguns dos "ateneístas" a posições de autoridade, como M iguel Alessio Robles e José Vasconcelos (ex-combatente nas guerrilhas antiporfiristas em 1911, posteriormente exilado por Huerta e Carranza). Assim, os reitores seguintes seriam, quase todos, antigos "ateneístas": Antonio C aso (de 1921 a 1923, depois da promoção de Vasconcelos ao cargo de secretário de Educação Pública, de 1921 a 1924), Alfonso Pruneda (de 1924 a 1928) e Antonio Castro Leal (de 1928 a 1930). Este último, que se proclamava discípulo de Pedro U reña, foi destituído com o triunfo da reforma universitária mexicana, promovida pelo recentemente reorganizado movimento estudantil e inspirada de um modo distante no exemplo e no programa da Reforma U niversitária argentina.

Cabe assinalar que, embora quase todos os "ateneístas" tenham permanecido confinados a espaços marginais do campo cultural mexicano durante a primeira década da Revolução, suas iniciativas culturais - que confluíam agora com o clima geral de reivindicação dos direitos sociais da massa da população - contribuíram para manter a visibilidade do grupo junto ao público - e isso apesar da inevitável dispersão devida a suas opções políticas divergentes e aos exílios impostos pela guerra civil. Entre 
1912 e 1920 havia funcionado, por exemplo, a Universidade Popular M exicana - centro alternativo à U niversidade N acional do M éxico (U N M ) e cujo reitor foi Alfonso Pruneda. Criada com a intenção de aproximar a educação universitária dos setores médios e operários da capital mexicana, participaram dela muitos dos principais membros do Ateneo: além de Pruneda, Pedro U reña e Reyes (até 1914), lecionaram ali M artín Luis Guzmán ${ }^{14}$, Vicente Lombardo Toledano ${ }^{15}$, M anuel Gómez M orín ${ }^{16}$ (autor de 1915, livro que buscou outorgar um perfil geracional próprio aos integrantes mais jovens do movimento liderado pelos "ateneístas", e futura fonte de inspiração ideológica do PAN [Partido de Acción Nacional]), Federico $M$ ariscal (arquiteto e um dos pioneiros da história da arquitetura colonial mexicana) e outros. Essa iniciativa contou também com 0 apoio explícito de um político que, no começo de sua longa trajetória, mostrava possuir todos os atributos do poder, o engenheiro Alberto Pani, subsecretário de Instrução Pública no governo de Francisco M adero (1911-1913) ${ }^{17}$.

A aliança feita por Vasconcelos com o grupo Sonorense levou os "ateneístas" a seu momento de maior prestígio e poder no campo intelectual mexicano. Vasconcelos dava início à sua campanha educativa com um ambicioso plano de edição e distribuição de clássicos filosóficos e literários, acompanhado de um projeto de alfabetização em massa - cujas conquistas imediatas se revelaram mais aparentes do que reais. Pedro H enríquez U reña buscaria dar nova vida ao projeto de educação operária - interrompido em conseqüência do desaparecimento da U niversidade 0 perária M exicana ao assumir o cargo de diretor do D epartamento de Intercâmbio eExtensão U niversitária, para o qual foi nomeado em 1921 por insistência de Vasconcelos. Com um quadro de 35 professores, entre os quais um número importante de "ateneístas", esse departamento cumpriu duas funções principais: aproximar dos setores populares a produção intelectual douta, mediante um ambicioso plano de conferências em fábricas, sindicatos e centros operários, e promover visitas de acadêmicos de outros países, como a de Franz Boas. Vicente Lombardo Toledano, por sua vez, foi nomeado para um cargo hierárquico no governo do D istrito Federal (1921), e depois para o de diretor do D epartamento de Bibliotecas da Secretaria de Educação da N ação (1922). D aí ele passaria a exercer o cargo de governador provisório do estado de Puebla (dez. 1923-mar. 1924). D istanciado de Vasconcelos por diferenças de critério quanto à direção da Secretaria de Educação, e dono de certo capital político próprio em conseqüência de sua posição de destaque no recentemente criado Partido Laborista M exicano e
14. Pouco tempo depois, ele se juntaria ao exército do Norte, liderado pelo mítico "Pancho" Villa, experiência que logo alimentaria uma parte importante de sua produção como novelista e en saísta. Ver Guzmán (1915; 1928; 1929), entre outros.

15. M embro da Geração de 1915, foi líder sindical epolítico socialista, especialista em filosofia jurídica e futuro mentor da Universidade 0 perária M exicana, criada em 1936.

16. Criou também a alcunha "Sete Sábios" para referir-se ao grupo de intelectuais - todos eles formados na esteira da renovação cultural promovida pelos "ateneístas" - que segundo eleteriam sido os verdadeiros artífices da nova cultura associada ao processo revolucioná rio do M éxico. Ao contrário dos "ateneístas", todos teriam sido "intelectuais de ação", predispostos a estar a serviço dos governos e das instituições da Revolução. Foram eles: M anuel Gómez M orín, Antonio Castro Leal, Alberto Vásquez del Mercado, Teófilo O lea y Leyva, Alfonso C aso (irmão 
mais jovem de Antonio), JesúsM oreno Baca e Vicente Lombardo Toledano. Na historiografia mexicana foi comum incorporar também $\mathrm{N}$ arciso Bassolsao grupo, inclusão julgada injustificada por Krause (1985), autor do estudo mais importante sobre o grupo. Em troca, a inclusão de Cosío Villegas, o "benjamim" das duas gerações (embora mantivesserelações intensas com ambas), entreosmembrosdaGe ração de 1915 contaria com mais elementos a seu favor. Ver K rause (1985).

\section{Segundo Cosío} Villegas (1977, p. 67), esse "sem dúvida eraum homem não só inteligente, maságil, que re presentou na história do M éxico a primeira invasão do tecnocrata nas fileirasrevolucionárias". No governo de Obregón, ele passou a dirigir a Secretaria de Re laçõesExteriores, econtinuaria exercendo al tos cargosnaadministração pública mexicana durante vários anos.

18. O bregón, como pre sidente, teria declarado, para explicar a abrupta mudança de rumo em sua política educativa(e na principal central operária - a CRO M - , Toledano recebeu sua nomeação diretamente do presidente 0 bregón. Pedro U reña - agora seu cunhado, pois dois meses antes havia se casado com sua irmã mais jovem, I sabel foi por ele nomeado secretário de E ducação de Puebla. Em meio à situação política turbulenta que a proximidade das el eições gerava em todo o país, 0 assassinato de um deputado opositor - cujo cadáver foi colocado na entrada do palácio do governo da província - frustrou o projeto de fazer de Puebla um bastião do "ateneísmo", quase ao mesmo tempo que Vasconcelos era obrigado a renunciar ao cargo de secretário da Educação ${ }^{18}$. Em 1924, tal como ocorrera em 1914, a fortuna política dos "ateneístas" tornava a cair por terra. M as havia, desta vez, duas diferenças importantes. Primeiro, a formação cultural promovida originalmente por Pedro U reña, Reyes, C aso e Vasconcelos parecia estar agora no centro do campo intelectual mexicano: os principais bastiões acadêmicos do país haviam passado para suas mãos, e o "novo humanismo" substituía o "positivismo" visto como irremediavelmente caduco. Apesar da dispersão do núcleo central do movimento, as posições de maior poder no campo intelectual mexicano segui riam controladas durante mais al guns anos pelos membros desse movimento ou por seus discípulos. A segunda diferença foi a dissolução definitiva do antigo núcleo "ateneísta". Se alguns de seus membros, como Reyes, Pedro U reña e Lombardo Toledano, continuaram mantendo durante muitos anos uma estreita relação, ela derivava agora não de sua comum participação no projeto "atenésta", mas de novos projetos culturais de al cance continental. 0 contexto mexicano já havia deixado de ser o único elemento determinante de sua posição na rede cultural ibero-americana.

Um périplo excêntrico e central: os "ateneístas" Pedro Henríquez Ureña e Alfonso Reyes

\section{0 desterrado $^{19}$}

$\mathrm{N}$ ão se pode compreender a trajetória intelectual de Pedro H enríquez U reña à margem de sua origem e posição no interior da cultura dominicana, país ao qual não retornaria quando adulto, com exceção de breves visitas nos anos de 1910 e uma temporada de dois anos na década de 1930. Pedro U reña não só pertencia a uma família que ocupava um lugar central no universo cultural dominicano, mas também, na distribuição de papéis que de um modo naturalizado se fazia no seio dessas famílias patriarcais - a 
exemplo doscélibatai res[solteiros] entreoscamponeses do Béarn, na França, estudados por Pierre Bourdieu -, Ihe coube o de homem de letras e continuador do empreendimento civilizatório de seus dois progenitores. D e antiga linhagem colonial por ambos os lados paternos, sua mãe, Salomé U reña, fora pedagoga e poetisa célebre, e seu pai, além das atividades de comerciante e médico, serviria em sua longa carreira política como embaixador e chanceler de numerosos governos mexicanos, e como presidente em 1916.

A precoce formação de Pedro U reña, e a atitude - 0 habitus - que 0 orientou em sua trajetória posterior por diversos campos intelectuais nacionais, assinala, primeiro, sua pertença a uma elite elevada e, depois, a perda desse lugar privilegiado. Em seus últimos anos em São Domingos, entre 1897 e 1901, Pedro e M ax - seu irmão mais jovem - assistiam às tertúlias organizadas pelas irmãs Feltz, pedagogas como sua mãe e formadas pelo Instituto de Señoritas. De Leonor, por quem parece ter sentido um afeto particularmente intenso, Pedro diria: "é hoje a mulher mais ilustrada de São D omingos". N as lembranças de Pedro, esses quatro anos foram sua última verdadeira belle époque, pois a partir de então seria expulso de sua posição de cômoda superioridade no topo da elite intelectual (e econômica) dominicana. Comentando essas tertúlias em suas lembranças, Pedro dirá:

U ma estupenda sensação de assombro causou em nós a leitura de Los espectros, seguida imediatamente por Casa de muñecas e H edda Gabler: na verdade, era uma revelação da vida moderna; essa classe de humanidade era a que eu parecia conhe cer, e não me explicava então como havia quem achasse raros esses dramas: enquanto eu conhecia mais de uma Elena Alving - mais de uma mulher superior - , via muitas outras na situação de N ora, epresumia semel hanças com H edda Gabler! Em realidade, eu convivera quase sempre com pessoas excepcionais; em meu país, sobretudo, conhecia todas as mulheres superiores; sabia que havia uma multidão de gente vulgar, conforme percebera na companhia de meus colegas, nas pessoas com quem lidava e que eu via nas festas sociais; mas o meu mundo, a minha gente, era assim, tinha a têmpera dos personagens de I bsen [...] (1989, pp. 61-62).

Em 1899 caíra o "tirano H eureaux", assassinado. A pós uma breve guerra civil, um governo de tendência liberal assumiria o poder em 1901, nomeando como chanceler Francisco H enríquez y Carvajal. Em 1901, partindo para os Estados Unidos a fim de dar início à missão que lhe fora em sua relação com Vasconcelos), que a Secretaria da Educação acabara se tornando uma amante muito cara.

19. Sobre Pedro H enríquez U reña, ver Lara (1975); ZuletaÁlvarez (2001); Inoa (2002). 
20. E não só nos Estados Unidos. Um inimigo político eintelectual, o escritor católico e nacionalista M anuel Gálvez (cujos Recuerdos de la vida literaria são, se gundo Beatriz Sarlo [2002], um artefato feito a cal har para a noção de "campo intelectual"), o descreveu com estudada malícia: "N ão me dei bem com seu irmão Pedro. Demonstravamá vontadecomigo eeu lhe correspondia amplamente. [...] Tínhamos tão pouca simpatia que no banquetea $\mathrm{H}$ ernández Catá (um escritor cubano), estando sentados um ao lado do outro, não trocamos uma palavra durante toda a noite. Eradecor bastante escura. Q uando veio pela primeira vez, creio que com Vasconcelos, ao saírem vários argentinos com os membros da comitiva de Vasconcelos do hotel onde se hospedavam, N oé assinalou-mePedro H enríquez Ureña, dizendo: 'Veja... Aqui consideramos negro a Ricardo Rojas, e ele pareceloiro ao lado desses' " (Gálvez, 2002, p. 656). encomendada, Henríquez y Carvajal convidou Pedro e seu irmão mais velho, Fran, para acompanhá-lo a N ova York. H ospedados numa pensão de luxo e com acesso à high soci ety nova-iorquina graças aos contatos e à posição política do pai, os dois irmãos fizeram cursos de inglês e se dedicaram principalmente a desenvolver uma agradável vida social dominada por sua paixão operística.

0 irmão mais novo M ax uniu-se a eles em 1902, e durante alguns meses o ritmo de freqüência a eventos musicais, que passou a incluir todo o repertório sinfônico, se intensificou. M as a fortuna política, como já ocorrera em 1901, voltou a intervir em suas vidas, agora de um modo mais contundente. A queda do governo dominicano em 1901 e o começo de uma cruenta guerra civil provocaram a ruína econômica e o exílio do pai. Para Pedro e seus irmãos, os resultados foram ainda mais catastróficos. Sem poder enviar-Ihes dinheiro e nem sequer pagar-Ihes as passagens, a ordem do pai foi peremptória: que buscassem trabalho, suprimissem quase todos os gastos e aguardassem a melhora de sua situação financeira, quando então os mandaria chamar.

"O rosto", disse Simmel, "é [... o o símbolo de tudo aquilo que um indivíduo trouxe consigo como pré-requisito de sua vida. N ele se depositou tudo aquilo que caiu como um sedimento de seu passado no fundo de sua vida, convertendo-se nos traços permanentes que marcam o indivíduo" (1997, pp. 112-113). O rosto de Pedro H enríquez U reña trazia, como se pode observar ao contrastar uma bela foto de juventude com outra - de rosto aflito - de sua velhice, não só a marca dos cruzamentos raciais operados pela conquista e pela escravidão africana, mastambém a de seus padecimentos depois de 1901. Privado da aura que até então Ihe outorgara sua posição na elite dominicana e sua distância de qual quer necessidade econômica, seu rosto, sobretudo para observadores racistas como eram tantos norte-americanos em 1902, se converteria agora num fator a mais para aguçar a débacle que os três irmãos haviam sofrido ${ }^{20}$. A experiência deixaria uma marca profunda no espírito de Pedro U reña: a complacente aceitação de sua natural pertença a uma jeunesse dorée daria lugar, aos poucose de um modo provavelmente não de todo consciente, a uma visão que - embora nunca deixasse de ser ameaçada pelo risco da illusio scholae que costuma marcar os habitantes do mundo acadêmico, com sua concomitante impossibilidade de ver as realidades mais próximas - se beneficiaria de uma fratura profunda em sua sensibilidade intelectual. Seu pensamento sobre a cultura latino-americana foi sempre habitado por uma tensão permanente 
entre sua vontade de elaborar uma obra filológica de profunda erudição destinada a um público minoritário e culturalmente muito exigente, ea de levar os bens culturais da elite ao "povo" - com um gesto mais "legitimista" do que "populista", certamente, se podemos empregar o vocabulário de Claude G rignon e Jean-Claude Passeron (1991). Tratava-se de uma tensão fecunda em muitos aspectos, da qual talvez se teria privado se não tivesse passado por sua dura prova nova-iorquina.

Enquanto os irmãos abandonavam seus estudos universitários para seguir um curso comercial de três meses com os recursos que Ihes restavam, Pedro buscou e encontrou um trabalho. Em suas próprias palavras:

[...] consegui um emprego de seis dólares semanais na N ichollas Tubing Company, situada na D écima avenida, perto da rua 54. M eu salário logo aumentou para sete e a seguir para oito dólares; mas as horas de trabalho eram longas, das sete e meia da manhã às seis da tarde, com apenas meia hora para o lunch, eo caráter do patrão era irascível esua educação quasenula. Era um Jerry Cruncher (A tale of two cities). Vi então de perto a exploração do operário: a maioria dos empregados eram muIheres e crianças; os poucos homens eram quase todos italianos que recorriam a mim para se fazerem entender; e e média dos salários era quatro dólares por semana. Aquelesforam dias amargos; nem sequer adquiri experiência comercial, pois os livros sofriam de uma antiqüíssima desordem, havia contas impossíveis de retificar e nunca fora feito um balanço. [...] No final, tive de sair dali, em julho de 1903, moído de corpo efatigado de espírito (1989, pp. 91-92).

A experiência de Pedro U reña, a partir de então, esteve sempremarcada por dois fatos fundamentais: sua condição de estrangeiro, de exilado permanente, mesmo durante os poucos anos em que voltou a residir em sua própria pátria, e sua relativa penúria econômica, que o obrigava a trabal har em ocupações muito afastadas de seu verdadeiro centro de interesse, salvo em esporádicos momentos de bem-estar. Como diria dele, anos mais tarde, Cosío Villegas:

$\mathrm{N}$ o fundo, Pedro era um homem triste, que carregava nas costas vel has e arraigadas preocupações. Raramente sentia o gozo da al egria, e raramente também conseguia rir de maneira franca, aberta. U ma grande parte desse peso provinha de sua história familiar: seus pais e seus dois irmãos, M ax e C amila, eram figuras ilustríssimas da República D ominicana, e no entanto poucas vezes, e apenas por períodos bre ves, conseguiram viver num país que caía freqüentemente na barbárie das piores 
ditaduras. Essa única circunstância fez de Pedro um verdadeiro judeu errante, um homem que busca sem repouso um pedaço de chão onde viver tranqüilo e seguro. E isso criou nele, também, um desejo agudo de conquistar uma posição independente das vicissitudes de nossos governos (1977, p. 96).

Sua vida, marcada sempre pela viagem permanente, passaria por quatro estações principais a partir de então. Residente em Cuba entre 1904 e 1906, passou em seguida a viver no M éxico. A primeira dessas estações (1904-1914) esteve circunscrita, portanto, ao marco geográfico do M éxico e do Caribe. Em Cuba - onde só Ihe havia parecido interessante a obra de Enrique José Verona -, colaborou no jornal fundado por seu irmão M ax, Cuba Literaria, e publicou seu primeiro livro, Ensayos críticos (1905). N o M éxico, como já foi indicado, forjou sua personalidade intelectual no movimento Ateneísta. A segunda estação, cujo começo coincidiu com o início da guerra européia e o momento mais crítico da Revolução M exicana, correspondeu a um novo eixo: Cuba-Estados U nidos-Espanha. Ele retorna a Cuba em 1914 para se encarregar de vários trabal hos jornalísticos, graças aos bons ofícios de seu irmão M ax. No mesmo ano, volta aos Estados U nidos, como correspondente de um diário cubano. Em 1916, como já mencionado, a derrubada de seu pai como presidente de São D omingos marcou a incorporação plena de Pedro U reña às correntes antiimperialistas, posição que manteria pelo resto da vida. Ao mesmo tempo, faz o doutorado na Universidade de M innesota, em literatura hispano-americana (1916-1918), sendo nomeado professor dessa disciplina ali (1918-1919, 1920-1921). Interrom pe brevemente sua estada em M innesota ao aceitar o convite de Alfonso Reyes para incorporar-se ao Centro de Estudos $\mathrm{H}$ istóricos em M adri, onde ficará dois anos (1919-1920). Além de seu trabalho como filólogo no Centro de Ramón M enéndez Pidal, em M adri ele colabora, com Reyes e o historiador marxista mexicano C arlos Pereyra, na primeira tradução ao castelhano de 0 Estado e a revolução de V ladimir Illich Ulianov, dito Lênin.

A terceira estação de sua longa peregrinação correspondeu à sua nova temporada mexicana (1921-1924), em que foi convocado por Vasconcelos para dirigir a Escola de Altos Estudos da UN M. Além de sua breve gestão como secretário de Educação do estado de Puebla, dois fatos decisivos marcam sua segunda residência no M éxico: seu casamento com I sabel Lombardo Toledano e seu primeiro contato com estudantes e intelectuais argentinos. Entusiasmado pela perspectiva de uma carreira universitária 
naquele país, e alentado pelas descrições talvez um tanto exageradas do ambiente intelectual argentino que lhe fizera o jovem líder estudantil e membro do grupo deAlejandro Korn na U N LP [U niversidade de LaPlata], H éctor Ripa Alberdi, ele visitará o país em 1922 (como membro da comitiva de Vasconcelos) e lá se instalará definitivamente em 1924. Sua situação de trabalho no M éxico nunca havia sido boa, embora na segunda estada tivesse obtido cargos de maior prestígio que na primeira. Além disso, preocupavam-no a instabilidade e a violência que percebia no M éxico revolucionário. Segundo Cosío Villegas, ele

[...] acreditava que o M éxico era "um país demasiado intranqüilo para o repouso a que tem direito um homem que entra na maturidade". Essa intranqüilidade não era criada pelas revoluções, era de caráter nacional. Pedro acreditava que, se fosse mexicano, julgaria um dever estar no país para ajudar a criar "um pouco de paz espiritual". M as não só isso: ele mesmo percebera que "nem sequer no M éxico se tolerava melhor o estrangeiro". D e fato, por mais de uma vez sentiu o rechaço ou a desconfiança de sua origem (1977, p. 97).

Assim, a quarta estação de sua vida errante correspondeu a seus longos anos na Argentina, entre 1924 e seu repentino falecimento em 1946; estação pontuada apenas por um brevee infeliz retorno à República $\mathrm{D}$ ominicana, de onde o ditador Rafael Leónidas Trujillo o convocara para a Superintendência Geral de Educação (cargo que correspondia ao de ministro), entre dezembro de 1932 ejunho de 1933; euns poucos meses em $\mathrm{H}$ arvard, na cadeira C harles Eliot N orton Professor, em 1940. Sem a possibilidade de concorrer a um cargo permanente e bem remunerado de professor na Faculdade de H umanidades da U N LP - por disposição expressa adotada nessa instituição, que proibia aos estrangeiros concorrer a um cargo (ele era o único quando foi tomada essa decisão) - , teve que se dedicar ao ensino secundário, o que implicou muitas horas de trabal ho roubadas de seu tempo de investigação e escrita. Instalado com a família numa pensão de Buenos Aires, viajaria durante quase todo o resto da vida detrem a La Plata, para lecionar no Colégio N acional. Em 1925 assumiu dois outros cargos, um no Instituto $\mathrm{N}$ acional do Professorado Secundário, em Buenos Aires, e outro como investigador (não remunerado) no recentemente criado Instituto de Filologia da U niversidade de Buenos Aires (onde em 1930 foi promovido ao cargo de secretário acadêmico). Somente em 1928 pôde iniciar sua docência universitária, como professor suplente de literatura da Europa 
21. A melhor caracterização deVossler esuaescola é a formulada por Auerbach: "A escola, chamadaidealista, deK. Vossler (1872-1949), influenciada pelas idéias acerca das épocas históricasenunciadas pelosfilósofos e historiadores alemães, inspiradasobre tudo na estética de Benedetto Croce(18661952), vêna linguagem a expressão das diversas formas individuais do homem, tal como estas se desenvolvem, numa evolução incessante, atra vés das sucessivasépocas dahistória. Vossler eseus seguidoresestudam, portanto, segundo a terminologia deSaussure, somente'laparole', não estudam 'la langue'; levam em conta apenas a prospectivahistórica; procuram encontrar nos fatos da evolução lingüísticaos testemunhos dacivilização das distintas épocas [...]; buscam nos fenômenos lingüísticos o gê nio particular dos indivíduos, dos povos, das épocas. É o grupo lingüístico da G eistexgeschichte[...]" (2001, p. 27). e setentrional, exercendo desde então, tanto na UN LP como na U BA [U niversidade de Buenos Aires], numerosas suplências e cargos temporários. Em 1931, finalmente, começou a ditar cursos no Colégio Livre de Estudos Superiores, atividade só interrompida por sua morte.

Apesar de suas dificuldades profissionais e de sua condição de estrangeiro, H enríquez U reña pôde articular, graças a suas relações transcontinentais com muitos dos principais escritores de sua geração, uma trama duradoura de intercâmbios, contatos e amizades intelectuais. N a Argentina, sua posição no Instituto deFilologia - ondelogo setornou um dos maisíntimos colaboradores de seu diretor, o espanhol Amado Alonso - o colocou em permanente relação com as principais figuras pertencentes a esse campo profissional, como Raimundo Lida, Ángel Rosenblat (muito mais jovem queele), Ángel Battistessa e G regorio $\mathrm{H}$ al perín. Sua passagem anterior pelo Centro de Estudos $\mathrm{H}$ istóricos da Espanha, dirigido por Ramón $\mathrm{M}$ enéndez Pidal - considerado então a autoridade máxima de língua espanhola no campo da filologia - , o fizera relacionar-se com a constelação de filólogos espanhóis organizada em torno desse centro:Tomás Suárez Tomás, Enrique D íez-C anedo, o poeta epintor J oséM oreno Villa, Américo C astro - um dos principais historiadores espanhóis no período posterior à Segunda Guerra M undial -, Antonio Solalinde, entre muitos outros. Embora tenha estabelecido uma relação cordial com muitos deles em sua passagem pelo C entro, convém sublinhar que, durante sua longa residência argentina, o principal vínculo que o manteve em contato com os escritores do centro madrilenho foi seu amigo íntimo e eventualmente seu discípulo Alfonso Reyes. N um campo definido pelas noções de "România" e de línguas "românicas", eque via em K arl Vossler (então o principal romanista alemão) seu gênio tutelar ${ }^{21}$, H enríquez U reña conquistou um lugar de indubitável prestígio por seus estudos da versificação eda métrica da poesia espanhola, suas análises da história lingüística do C aribe e seu esquema das grandes divisões dialetológicas naAmérica hispânica.

Suas principais ligações no campo intelectual argentino, porém, tiveram a ver com seu papel na revolta antipositivista no M éxico, sua militância antiimperialista e sua integração às redes formadas pelos dois principais partidos de esquerda, o socialista e o comunista. Autor do prólogo das obras completas, póstumas, de Ripa Alberdi - que, além de seu papel no movimento estudantil, tivera uma participação destacada no Colegio N ovecentista, ponta-delança da revolta antipositivista argentina -, H enríquez U reña integrou-se ao círculo do filósofo Alejandro Korn, introdutor 
do bergsonismo na Argentina e autor de um dos textos pós-positivistas de maior repercussão no ambiente local, La libertad creadora (1925). C onvertido em colaborador assíduo da revista de K orn, Valoraciones- versão mais acadêmica da renovação vanguardista e juvenilista da cultura argentina nos anos de 1920 -, ele manteria um forte vínculo com o campo filosófico que começava então a profissionalizar-se naquele país. D epois do falecimento de Korn, U reña seguirá mantendo uma estreita amizade com o filósofo herdeiro do seu prestígio, Francisco Romero - scheleriano com forte influência neokantiana e autor de um livro que teve certa ressonância fora dos limites estritos de seu campo profissional, La teoría del hombre(1935). Seus vínculos com a esquerda comunista e socialista eram, pode-se dizer, mais que ideológicos, de parentesco. Filho de um dos principais portavozes do antiimperialismo dominicano nos anos de 1920, irmão mais veIho de um companheiro de estrada do comunismo cubano e casado com a filha do líder da principal força marxista do M éxico entre os anos de 1920 e 1960, dificilmente H enríquez U reña podia eludir o sistema de relações sociais e intelectuais que lhe ofereciam os principais partidos marxistas de sua época. Seu entorno, potenciado por sua complexa trajetória vital e pela forma mentis que ela havia engendrado, o aproximou assim de diversas instituições vinculadas com a esquerda. Seu antiimperialismo o levou a apoiar a U nión Latinoamericana fundada por Ingenieros e dirigida por Alfredo Palacios e M anuel Seoane (um aprista [adepto da Apra, Alianza Popular Revolucionaria Americana]), enquanto sua antiga preocupação com a educação operária o faria converter-se num colaborador entusiasta tanto do Colégio Livre de Estudos Superiores como da Universidade Popular Alejandro Korn (em La Plata). Finalmente, como conseqüência, em primeiro lugar, do cruzamento de todos esses elementos de sua trajetória como intelectual e, em segundo e talvez mais importante, do fato fundamental de ter sido reconhecido como um dos grandes prosadores da língua espanhola a partir do primeiro livro importante de sua etapa argentina, Seisensayos en busca denuestra expresión (1928), Pedro H enríquez U reña passou a fazer parte do conselho editorial da revista de Victoria 0 campo, Sur, de 1931 até sua morte em 1946. No círculo da Sur, desenvolveu uma relação muito proveitosa, embora certamente nada fácil, com Jorge Luis Borges: os dois pertenciam a campos opostos no debate em torno da gramática espanhola ocorrido no final da década de 1930 (embora não tenha criticado a Gramática castellana escrita por Amado Alonso e Henríquez U reña, o feroz ataque de Borges a Américo C astro, que interviera na dis- 
puta a favor de seu compatriota e do dominicano, não deixou dúvidas sobrequal era sua posição). M esmo assim, os dois publicaram juntos, como co-editores, em 1937, uma Antología clásica dela literatura argentina. Como se evidencia pelo exame mais superficial dos trabal hos de Borges feitos em colaboração com outros, a amizade e o respeito eram condição sine qua non desses empreendimentos. Por outro lado, a chegada do editor espanhol Ángel Losada a Buenos Aires, em 1937, ofereceu a H enríquez U reña a oportunidade de ocupar novamente uma posição de influência no mundo editorial, como acontecera no M éxico com a Editorial Cultura de Julio Torri. Acionista e diretor técnico da editora Losada (outro diretor técnico foi Francisco Romero, vinculado havia mais tempo com o editor espanhol), U reña foi responsável por duas coleções de grande divulgação e importância: "Cien obras maestras de la literatura y del pensamiento universal" e "Grandes escritores de América". N a primeira publicaria traduções ao castelhano de H omero, Ésquilo, Shakespeare, Plutarco, além de clássicos espanhóis, todos com uma introdução ou um prólogo de sua autoria; na segunda editaria N uestra América de José M artí, M oral social de Eugenio $M$ aría de $\mathrm{H}$ ostos, e outros clássicos, também com prólogos redigidos por ele. Amigo e colega de Ezequiel M artínez Estrada, de Carlos Sánchez Viamonte - delegado da U nión Lationoamericana enviado em missão ao Peru na década de 1920, dirigente da "esquerda" do Partido Socialista nos anos de 1930, advogado oficial do Partido Comunista e deputado nacional pelo Partido Socialista entre 1941 e 1943 -, de Roberto Giusti, de Ernesto Sábato, do círculo do grupo Sur, do promotor cultural e futuro editor da Fondo de Cultura Económica Arnaldo O rfila Reynal, dos dois Romero, José Luis - o historiador - e Francisco, H enríquez U reña ocupou um lugar ao mesmo tempo central e excêntrico no campo cultural argentino de sua época. Foi essa posição idiossincrática, simultaneamente de insider e outsider, que não só fez dele um dos eixos polares de uma constelação que encontrou seu outro pólo - na Espanha, em itinerância diplomática pelo Brasil, Argentina ou França, e finalmente no M éxico em outro marginal ilustre, Alfonso Reyes, como também Ihe permitiu ser o grande sintetizador - em suas últimas obras, especialmente em sua $\mathrm{H}$ is toria de la cultura en la América Hispánica - da nova história cultural "continentalista". 


\section{0 átrida ${ }^{22}$}

$N$ ascido em 1889 no seio de uma família pertencenteà elite mexicana, a morte do pai como rebelde contrário ao regime instaurado pela Revolução selou o destino futuro de Alfonso Reyes. No dia 9 de fevereiro de 1913, quando comandava um assalto ao palácio presidencial, o general Bernardo Reyes foi atingido pelas metral hadoras que defendiam o governo de $M$ adero. Para Alfonso Reyes, esse 9 de fevereiro foi um verdadeiro turning-point, o momento decisivo de uma mudança no curso do seu destino. Pontuando as páginas de sua extensa obra, às vezes com toda a força de seu som crispado e metálico, outras vezes como se viesse de longe ou estivesse abafado, ouve-se aqui e ali o ruído da metral hadora que abateu seu pai nesse dia tão infausto. A té certo ponto a personalidade adulta de Alfonso plasmou-se em torno do mito que ele mesmo criou acerca do pai, e épor isso que, em suas evocações autobiográficas, a lembrança desse homem, que em realidade ele nunca chegou a conhecer, raramente deixa de fazer sentir sua presença ${ }^{23}$.

D e uma maneira também semelhante à experiência vital dos $\mathrm{H}$ enríquez U reña - embora no quadro de suas vidas tenha sido definida por fatores diversos - , Alfonso Reyes foi expulso de seu assento privilegiado no mundo da elite mexicana. A decisão de Rodolfo e outros de seus irmãos de apoiar Victoriano H uerta selou o destino final dos Reyes. N um clima de fim de regime, marcado pelo avanço sobre a Cidade do $M$ éxico dos vários exércitos revolucionários, Alfonso Reyes, cuja abstenção ante a atividade política de seus familiares era conhecida, buscou fugir do palco de guerra em que logo se converteria a capital mexicana, aceitando a nomeação, feita por H uerta, de secretário da missão diplomática do M éxico na França. Sua transferência para Paris, em 1914, marcou o início de um longo exílio que só terminaria definitivamente em $1939^{24}$.

A vitória do general Venustiano Carranza sobre H uerta foi acompanhada da demissão de todos os funcionários nomeados pelo regime extinto, inclusive os que ocupavam cargos diplomáticos. M ais grave, do ponto de vista da família, foi o confisco de todas as propriedades decretado pelo governo revolucionário. Reyes teve que passar pela mesma experiência de penúria econômica numa grande cidade - neste caso Paris, e não N ova York - dos irmãos H enríquez U reña. Pior ainda, no mesmo mês em que deixou de receber seus vencimentos - agosto de 1914 -, começou a Primeira G rande Guerra. Acompanhado da esposa e do filho, tocou-Ihe viver de perto o clima de mobilização militar que invadiu a outrora capital da
22. SobreAlfonso Reyes, ver Garciadiego (2002); M artínez (1992); Patout (1990); Reyes Jurado (1972); W illis (1965). Sobre a viagem intelectual de Reyes, ver C olombi (2004).

23. Em seu excelenteestudo sobre Reyes, Garciadiego (2002) sugeriu queaficcionalização da figura paterna efetuada pelo ensaísta - nunca teve veleidades intelectuais, não tinha bom gosto literário, preferia a pior poesia românticaàmodernista- foi seu modo deapropriar-sedo pai ausente, e ao mesmo tempo traçar uma linhagem intelectual mais prestigiosa que a que realmente lhe correspondera.

24. D epoisdeseu rallie ment ao regime revolucionário, em 1920, sua condição deexilado variou de nome, mas não de realidade. Embora convertido em funcionário pago pelo Estado revolucionário, eembora lhe fossem permitidas breves visitas ao M éxico para receber instruções sobre seus futuros destinos diplomáticos, uma conversa com Antonio Caso re vela qual era sua verdadeira situação: ao que 
parece, Caso disse-lhe que podia retornar ao M éxico sequisesse, mas que o melhor era que não o fizesseduranteum bom tempo. Até 1938, essa parece ter sido a respostaconstanteasuas esporádicastentativas de saber se seu ostracismo havia terminado. belle époque, as privações causadas pelo racionamento de artigos básicos de consumo e a ameaça de morte pelo avanço das tropas al emãs e os bombardeios. Em meados de setembro, julgando insuportável sua situação em Paris e valendo-se da oferta que o governo francês Ihe fizera - devido à sua condição de ex-diplomata - de transporte gratuito até a nova sede do governo nacional em Bordeaux, ele iniciou sua fuga para o sul. D epois de alguns dias em Bordeaux, decidiu seguir viagem para a Espanha, com a intenção de tentar a sorte no âmbito literário madrilenho.

Em M adri, obrigado pela primeira vez a buscar um trabalho assalariado, viveu como pôde como tradutor e jornalista. Sua amizade com os $\mathrm{H}$ enríquez U reña Ihe valeu a nomeação de correspondente do $\mathrm{H}$ eraldo de Cuba em $\mathrm{M}$ adri, ao mesmo tempo que se encarregava eventual mente de traduzir livros como a H istória da Grande Guerra, do historiador francês H anoteaux. Sua situação começaria a melhorar em meados de 1915, à medida que passava a circular e a ser conhecido pelos escritores e intelectuais que dominavam o pequeno campo literário madrilenho. No Ateneo de M adri, cujas reuniões passou a freqüentar com a expressa intenção de conhecer os escritores espanhóis, travou uma forte amizade com Enrique D íez-C anedo, crítico teatral e filólogo que o tomou sob sua proteção. Por intermédio dele, foi contratado como crítico de cinema pelo semanário de osé 0 rtega y Gasset, España. (Alfonso, alguns meses mais tarde, ajudaria um outro "ateneísta" exilado, M artín Luis G uzmán, a obter igual nomeação. A coluna de crítica de cinema, chamada "C hispita", passou a ser redigida a quatro mãos.) A partir de então, começaria uma carreira de jornalista nos principais periódicos e publicações de 0 rtega y $G$ asset, a cujo círculo - embora numa posição muito marginal - seunira. Em meados de 1916, havia alcançado uma posição estável e uma carreira no mundo editorial e jornalístico relativamente exitosa. Foi nessa conjuntura que se integrou à equipe de filólogos que pertenciam ao Centro de Estudos Históricos de M enéndez Pidal. Junto com o filólogo espanhol Antonio Solalinde, ficou encarregado da seção de resenhas da Revista de Filología Española. Entre 1916 e 1919 integrou-se progressivamente na vida intelectual espanhola: além do círculo de $O$ rtega e de seus companheiros no Centro de Estudos $\mathrm{H}$ istóricos, estabeleceu alianças sólidas com M anuel Azaña - futuro presidente da Segunda República espanhola - , com Juan Ramón Jimenez - então no auge de sua carreira literária - e com outras figuras que ocupavam um lugar central nas letras espanholas. No entanto, seu trabal ho defilólogo, quelogo Ihe permitiria real izar os estudos que integraram muitas de suas antologias 
mais importantes - como Q uestiones gongorinas - , 0 aborrecia. Ao contrário de Pedro H enríquez U reña, que via na filologia o topo da carreira de letras, a única profissão moderna que encarnava o ideal de "um novo humanismo", Reyes preferia o trabalho mais puramente literário: a escrita de ensaios, de poesia ou de prosa de ficção. A figura de intelectual com a qual mais se identificava era a do "homem de letras", não a do "escritor profissional" e muito menos a do "acadêmico" filiado a uma disciplina universitária específica. Considerando, como diria em carta a Pedro U reña, que o trabalho no Centro era puramente "manual" e sem valor "espiritual" algum, decidiu afastar-se do instituto em 1919, aproveitando uma oferta feita por amigos então integrantes do governo mexicano para incorporar-se à Comissão H istórica M exicana, cuja primeira missão, depois de ser refundada por $C$ arranza, era registrar os arquivos espanhóis. Esse convite aproximou o governo revolucionário do M éxico e Alfonso Reyes, e serviu de antecedente para que 0 escritor pudesse ser reincorporado, após outra mudança de governo em seu país, à carreira diplomática em 1920 (com o apoio, novamente, de Vasconcelos). Se Alfonso culpava seu irmão Rodolfo pela morte do pai, este, apoiado pelo setor da família que o seguia, acusava o irmão mais jovem de ter injuriado a memória do bravo general eter faltado aos deveres impostos pela piedade filial ao aceitar uma nomeação das mãos do regimeresponsável por sua morte. A exemplo dos átridas gregos, 0 sangue paterno derramado acabou cindindo - como herança fatal - a linhagem dos Reyes em partes inconciliáveis.

D urante os dezoito anos seguintes, Alfonso viajaria pela Europa e pelo continente americano como representante diplomático do governo mexicano. Entre 1920 e 1924 esteve encarregado da missão diplomática na Espanha. N essa segunda estadia espanhola, pôde aprofundar e ampliar seus vínculos com os diferentes grupose movimentos que definiam o mapa literário daquele país. Em 1923, o círculo de 0 rtega Ihe ofereceu uma primeira consagração importante ao incorporá-lo como colaborador-fundador de redação da Revista de 0 ccidente, destinada a ser a publicação de maior impacto intelectual no mundo hispanófono nos anos de 1920 e 1930. Ao mesmo tempo, sem distanciar-se de seus amigos das gerações de 1898 e de 1914, começou a freqüentar os novos círculos literários de vanguarda, que deram origem à terceira geração da "Idade de Prata" das letras espanholas, a de 1927. García Lorca, Gerardo D iego, Luis Cernuda, Rafael Alberti e muitos outros representantes da geração emergente encontraram acolhida no sistema de sociabilidade que os recursos de sua embaixada Ihe permi- 
tiam agora elaborar. Em 1924 pôde voltar por alguns meses ao M éxico, tendo demonstrado previamente sua leal dade ao regime ao opor-se publicamente à rebelião "delahuertista" do ano anterior. Seu destino seguinte seria Paris, um prêmio pelos serviços prestados ao governo de 0 bregón durante sua breve missão ad hoc junto ao rei da Espanha, entre 1924 e 1925. Ao cabo de onze anos, a etapa espanhola da vida de Reyes havia terminado, mas as amizades literárias ali formadas continuariam incorporadas ao circuito epistolar cada vez mais amplo que ele foi articulando a partir das diferentes embaixadas que Ihe coube dirigir.

Sua segunda residência francesa, como chefe da missão diplomática nesse país (1925-1926), permitiu-lhe também criar al gumas relações com figuras do universo intelectual francês, mas sua presença na densa trama de escolas, movimentos e mandarins intelectuais, na Paris do período entre guerras, foi bem mais marginal do que na Espanha. Ele aproveitou seu tempo ali sobretudo para inteirar-se das novas correntes literárias e filosóficas, para ampliar seu conhecimento da tradição cultural francesa e para promover sua própria obra entre os intelectuais parisienses mais receptivos à produção hispano-americana. 0 s nomes de seus principais interlocutores não surpreendem muito, já que o foram também de escritores e artistas argentinos, como Ricardo Güiraldes, ou brasileiros, como 0 swald de Andrade eTarsila do Amaral: Valéry Larbaud, o franco-uruguaio Jules Supérvielle, Jean Casou (que seria um de seus tradutores ao francês). Além disso, chegou a vincular-se a vários escritores que pertenciam, como ele, ao mundo diplomático: Paul Claudel e Paul Valéry, entre outros.

0 destino seguinte o trouxe de volta ao continente americano: Buenos Aires. Ali, entre 1926 e 1930, desenvolveria uma intensa atividade literária, vinculando-se também aos princi pais grupos que disputavam o campo cultural argentino, embora com uma marcada preferência pelos "martinfierristas" e os promotores de N osotros, de um lado, e pel os setores antiimperialistas e de "esquerda", de outro. Sua fina apreciação da literatura francesa permitiu-Ihe estabelecer uma duradoura aliança com o antigo diretor da Biblioteca N acional, um dos historiadores mais prestigiosos da época, de origem francesa: Paul Groussac. Ao mesmo tempo, como acontecera com Vasconcelos poucos anos antes, encontrou um firme aliado da renovação cultural que os "ateneístas" haviam promovido no M éxico em Ricardo Rojas, então reitor da U niversidade de Buenos Aires. M as, ao contrário de Vasconcel os e H enríquez U reña, mais atraídos pelo ensaísmo - erudito ou de militância político-cultural -, as verdadeiras afinidades eletivas de 
Reyes, tanto naArgentina como no Brasil, pertenciam ao mundo da criação literária, como Victoria 0 campo e seu círculo, Jorge Luis Borges e um amplo leque de poetas, entre os quais o então muito jovem Ricardo M olinari ocupava um lugar de destaque. 0 reencontro com $\mathrm{H}$ enríquez $\mathrm{U}$ reña parece ter resultado menos agradável do que o esperado, pois, segundo os diários de Reyes, os longos anos de separação haviam transformado os dois. É possível supor que a aposta de U reña numa carreira acadêmica profissional, a qual, sem separá-lo completamente de sua primitiva vocação intelectual de "mestre" das juventudes americanas, tendeu a reduzir o raio de projeção de sua obra, tenha provocado em Reyes uma reação semelhante à de outros críticose poetas latino-americanos- embora amortecida pela retórica da amizade. No começo dos anos de 1920, o ensaísta chileno Armando D onoso havia acusado H enríquez U reña (colocando a seu lado o então filólogo do Centro de Estudos H istóricos, Reyes) de tomar um "caminho extraviado"; declarava temer que o dominicano e seus discípulos seguissem o mesmo triste destino de M enéndez Pelayo, em cujo espírito "o bibliógrafo consumiu o homem de idéias" (D onoso, 1925). Em seu livro de viagens e reflexão cultural publicado em 1935, Continente vacío, o irônico poeta mexicano Salvador N ovo - da geração dos "C ontemporáneos" e, portanto, muito mais jovem que os "ateneístas" - esboçaria um retrato de calculada crueldade de $H$ enríquez U reña, no qual enfatizava o entusiasmo transbordante com que o dominicano Ihe havia narrado suas investigações acerca da origem dos termos "boniato" [búnio, espécie de planta umbelífera comestível] e "papa" [batata]. M as, ainda que Reyes, tendo decidido afastar-se definitivamente da disciplina estrita da filologia em busca de um estilo de escrita mais livre, pudesse compartilhar algo da desilusão manifestada pelos hispanoamericanos que o haviam conhecido em sua primeira juventude, a relação entreeleeU reña permaneciafirme, pelo menosatéa segunda visita de Reyesà Argentina. M aría Rosa O liver, em suas memórias, os retratou compartiIhando numerosos jantares e encontros, dirigindo brincadeiras um ao outro, ou fazendo um chiste mais pesado sobre algum dos demais concorrentes. Segundo essa escritora,

[...] a embaixada do M éxico na rua Arroyo logo se converteu num lugar onde se reuniam escritorese artistas detodo o país, até então desvinculados entresi, ou que mutuamente se ignoravam, e ali os argentinos tinham a oportunidade de trocar idéias com colegas vindos do resto da América e da Europa num ambiente descontraído e cordial: não por diplomático, mas porque sua ironia fazia tomá-los 
cum grano salis, Alfonso Reyes era simples e natural em seu trato com os notáveis "de passagem" (1969, p. 234).

M as nem sempreera "descontraído e cordial" o ambiente, sobretudo quando se tratava de certos "figurões" daqueles anos, como o conde Keyserling:

Ele sentou-se ao piano e, acompanhando-se com maestria, pôs-se a ulular cantos de som selvagem que interrompia para pedir champanhe ou para que se aproximassem as garotas mexicanas de corpos bem torneados que o observavam com olhos cheios de riso. $\mathrm{N}$ em bem tinha uma a seu alcance, pegava-a com um braço enquanto com a outra mão seguia martelando o teclado ou empinando uma taça atrás da outra. Com vertiginosa rapidez foi esvaziando as garrafas dos cai xotes que, para consumo exclusivo de seu hóspede, Alfonso Reyes mandara colocar num canto da sala. As canções faziam-se cada vez mais ululantes e pontuadas por soluços, enquanto as mexicanas buscavam dissimuladamente pôr-se fora do alcance das mãos daquele que, nesse momento, o anfitrião tratava, entre dentes, de "Bárbaro que não sabe viver entre gente civilizada", ou com um "Veja só que conde!". E M anuela, sua mulher, não parava de rir do conde embriagado [...] (I dem, p. 255).

D a mesma forma que em seus destinos anteriores, ou como depois no Brasil, R eyes aproveitou a passagem pela Argentina para ler sobre sua literatura e sua história, e para elaborar uma interpretação geral de sua cultura que pudesse integrar-se àquela mais vasta que, desde seu antigo ensaio Visión de Anáhuac, ele estivera tentando estender para toda a América Latina. N esse sentido, e a exemplo de Vasconcelos e de Pedro H enríquez U reña, o deslocamento físico de um país do mundo ibérico a outro e o contato intenso efluido com seus campos culturais- tão diversos entresi - permitiram-Ihe elaborar uma representação do "Iatino-americano", condensada numa série de imagens e hi póteses que logo embasariam todo o projeto da história cultural latino-americanista e seu diálogo tão fecundo com o ensaísmo de interpretação nacional. Como diria com sua inimitável retórica, num dos discursos pronunciados em Buenos Aires, seu périplo de viajante cultural, corolário de seu serviço diplomático em defesa da causa da Revolução M exicana, era motivado em grande parte pelo desejo de obter uma visão panorâmica desses povos:

E todo amor é guloso. Um apetite desperta outro. Vamo-nos afeiçoando com a idéia de viver em toda parte e em nenhuma, como num vôo de pássaro, e um 
pouco sobre as cristas movediças do tempo. Vai-nos seduzindo essa ânsia de penetração no sabor de todas as comarcas, esse gosto de provar e contrastar fronteiras, essa embriaguez de ver avançar ao mesmo tempo as tropas de todo o mundo, esse mareio panorâmico da terra, do qual os aviadores saberiam um pouco se sua viagem fosse como a nossa - não nas dimensões do ar mas através do coração dos povos (apud Robledo Rincón, 1999, p. 111).

Em seu discurso intitulado "Palavras sobre a nação argentina”, emitido primeiro por rádio e depois publicado na revista N osotros (com cujos editores, especialmente G iusti, ele havia estabelecido uma forteamizade), Reyes ampliaria esse conceito numa linguagem levemente menos poética:

H ouve um tempo em que cada nação americana queria conhecer-se a si mesma por um ato de mística penetração, ou então considerando-se como aproximação e já que não como decadência - como repercussão ou eco de algum sonhado modelo de nacionalidades, de algum contrato institucional teórico, inventado por pensadores e políticos de outros povos. E o conhecimento de nós mesmos não dava nenhum passo adiante. M as há poucos lustros - enunca insistiremoso bastantena importância dessa descoberta - inventamos um equivalente da Gramática Comparada entre as nações da América hispânica, e acredito que, antes de poucos lustros também, teremos recuperado o tempo perdido. Q uero dizer que apenas começamos a nos comparar uns com os outros, e que de tal comparação há de nascer um conhecimento mais exato do ser nacional (Idem, pp. 165-166).

Sobre uma base de comparação entre o que ele acreditava serem então "os dois pólos da América", M éxico eArgentina, Reyes esboçou com pinceladas firmes e hipóteses fortes uma interpretação do caráter nacional argentino, marcado por seu traço de país de deliberada criação artificial, pelo conflito latente, como na Roma dos senadores, entre o patriciado autóctone e o demos de origem estrangeira, e pela necessidade de disciplina social sintetizada no vinco perfeitamente passado a ferro das calças masculinas dos argentinos - que devia suprir a falta de tradições e de costumes, de moeurs, no sentido de Voltaire e M ontesquieu. N essa "miniatura argentina" aparece também uma notável observação sobre a diferença entre a Argentina e os Estados Unidos:

M ais que uma nação de transporte ou depósito histórico, a Argentina éuma nação de criação voluntária. A consciência dos homens, dos indivíduos, a produziu. É 
quase o fruto de um desejo. 0 colono encontrou aqui tribos nômades sem jazigos de civilização, e teve que importar tudo - até os parasitas! Fruto de um desejo e fruto leigo; filha de uma aspiração cívica. E nisso ela se diferencia dos Estados U nidos, que ainda são o fruto - em sua origem - da aspiração religiosa dos quacres. Aquel es peregrinos buscavam a liberdade de orar. Estes colonos vêm buscando um campo onde semear uma nação feita à sua medida (I dem, pp. 169-170).

0 que cabe ressaltar nessa passagem não éa pertinência ou não da observação de Reyes - como toda generalização, pode ser objetada de distintos ângulos, e além disso padece da inegável vontade de "ganhar amigos" (frase que ele gostava de citar acerca das obras de Juan Ruiz de Alarcón) que cerceava a liberdade de opinião do diplomata em terra al heia - , mas a vontade de criar imagens sintéticas que servissem para condensar toda uma interpretação altamente complexa da cultura nacional observada - neste caso, a argentina - e sua relação com a América Latina. Essa vontade de plasmar em "figurações" a interpretação da realidade cultural do continente latinoamericano seria o eixo em torno do qual se articularia o projeto da história cultural, promovido quinze anos mais tarde por toda essa falange de escritores integrados ao circuito lábil e permanente de intercâmbios que o sistema epistolar do diplomata mexicano soube ser.

25.Para a descrição a seguir, baseei-me fundamentalmentenaobra de Ellison (2002).
Entre 1930 e 1936, Reyes residiu no Rio deJ aneiro como embaixador ${ }^{25}$. Como na etapa argentina, aproveitou a permanência no país para familiarizar-secom a história brasileira eespecial mente com seu campo literário. Seu primeiro contato - a quem solicitou ajuda para orientar-se no novo meio cultural - foi Ronald de Carvalho, velho amigo de Vasconcelos e também conhecedor do M éxico. Por meio dele pôde vincular-se à Fundação G raça Aranha, iniciando alguns contatos literários que foram além do mero convívio social queacompanha as funções rotineiras deum diplomata. Embora seu círculo carioca de amizades literárias pareça ter sido menos extenso que aqueles que formara na Espanha ou na Argentina - a barreira do idioma certamente influiu -, Reyes estabeleceu ligações sólidas com algumas das figuras mais importantes do espaço cultural brasileiro. D esde sua chegada ao Rio, desenvolveu uma relação cordial com Gilberto Freyree com 0 artista Cícero Dias, baseada, no caso do primeiro, num mútuo respeito intelectual. D urante al guns meses, os três mantiveram o costume de nadar juntos numa praia. Reyes freqüentou também vários pintores que residiam na cidade, como Cândido Portinari eEmiliano Di C avalcanti, reatou sua velha amizade parisiense com 0 swald de Andrade (a quem considerava, no en- 
tanto, demasiado "vanguardista" e errático para compartilhar seu projeto ideológico-literário) e conheceu sua nova companheira, Pagu. Por ocasião da visita de Paul M orand - como Blaise Cendrars, um infatigável viajante-, participou de vários encontros com o célebre romancista, incluindo uma visita noturna a um centro de macumba afro-brasileira, em companhia também do poeta M urilo $M$ endes, de Cícero D ias e de um guia negro. Contudo, sem diminuir os laços intelectuais estabelecidos com Freyre, cuja obra Reyes acompanharia desde então, suas referências mais importantes no país parecem ter sido Alceu Amoroso Lima (Tristão de Athayde), M anuel Bandeira e Cecília M eireles. Com o ensaísta católico manteve uma prolongada relação mesmo após a partida do Brasil, apesar de, dadas as posições que ocupavam em seus respectivos campos intelectuais, terem poucos pontos em comum: desde seu reingresso na carreira diplomática, em 1920, Reyes esteve publicamente comprometido com a política mantida pelos sucessivos governos revolucionários no M éxico, o que implicava seu apoio à causa anticlerical na luta entre I greja e regime. Tudo parece indicar também que Reyes - ainda que, por tratar-se de um autor cujo domínio da retórica (e sobretudo da capacidade de dar expressão irônica à ambigüidade) era magistral, sempre exista a possibilidade de que não se consiga captar realmente o personagem íntimo - compartilhou com outros membros de sua geração 0 entusiasmo pelas transformações sociais e culturais quea Revolução M exicana havia prometido ao povo. Seu discurso público sempre manteve uma fina sintonia com as diretrizes emanadas da chancelaria mexicana, mas também com as idéias e os valores que integraram a esperança naquilo que H enríquez U reña denominara "a utopia da América". Ao lado do discreto fervor "revolucionário" que o animava, um agnosticismo irônico e distante parece ter sido um dos elementos constitutivos de sua personalidade. Embora não fosse - como de fato não foi - um obstáculo insuperável para a manutenção de uma longa e cordial conversa intelectual mediante a barreira ideológica que os separava, isso implicava, do ponto de vista do projeto cultural e literário de Reyes, que sua amizade com Amoroso Lima dificilmente poderia traduzir-se em colaborações intelectuais de mais envergadura que a epistolar. Por outro lado, sua relação com os dois poetas - a jovem eentusiasta C ecília M eireles e o amável eboêmio M anuel Bandeiraparece ter sido não só privada desses impedimentos como também mais intensa. 0 respeito mútuo entre Reyes e Bandeira foi expressado na inclusão de um parágrafo de autoria do primeiro como epígrafe justificativa em M afuá do malungo, na participação de Reyes como único hispano-america- 
no no livro coletivo H omenagem a M anue Bandeira, enas duas poesias de Bandeira referidas a R eyes - entre elas a justamente célebre "Rondó dos cavalinhos". No caso de Cecília M eireles, tanto sua correspondência com Reyes como os artigos elogiosos por ela publicados sobre sua obra e seus discursos testemunham a admiração intelectual que sentia pelo embaixador quarentão que acabara de conhecer e que certamente também a estimava, como se depreende de fragmentos de seu diário e de sua correspondência. (N um plano mais pessoal, existea possibilidade- embora, segundo Ellison, provas concretas ainda não tenham sido encontradas - de quea grande poetisa tenha sido a inspiradora da louca paixão despertada por uma brasileirasegundo diversas testemunhas - em Reyes durante sua estada no Rio de Janeiro. Por ora, e talvez para sempre, sua identidade deverá permanecer envolta em mistério, qual uma dark lady shakespeariana.) Seja como for, os seis anos no Rio tiveram um impacto decisivo sobre o americanismo de Reyes: a experiência direta e prolongada da real idadebrasileira - ainda quea partir do cômodo mirante de uma embaixada estrangei ra que o protegia de qual quer risco, salvo o das penas de amor - permitiu-Ihe aprofundar e refinar sua visão da cultura latino-americana, incorporando deforma decisiva a exemplo do fulgurante Vasconcelos, mas diferentemente de $\mathrm{H}$ enríquez U reña- a cultura brasileira.

Reyes não parece ter exercido maior impacto sobre os meios culturais brasileiros durante sua permanência no país: fora de suas atividades estritamente profissionais, e como parte de seu desejo de ampliar 0 alcance de sua obra, ele pronunciou no Rio, em meio aos brindes e saudações de ocasião, pelo menos dois discursos destinados a serem muito célebres, ambos dirigidos a um público de estudantes universitários. Um deles, "Atenea política", marcou um dos momentos de maior condensação de seu ideário americanista, sendo uma daquelas pequenas gemas espalhadas pelas milhares de páginas de suas obras completas: teve certa repercussão na imprensa brasileira (e uma grande difusão nos circuitos culturais hispano-americanos por meio de M onterrey, o "correio - em realidade um periódico unipessoal literário" queele editava), mas a audiência de sua primeira leitura parece ter sido escassa. Além da barreira do idioma, as condições políticas complexas que imperavam no Brasil nos anos que prepararam o advento do Estado $\mathrm{N}$ ovo não parecem ter sido as mais propícias para despertar um grande entusiasmo pelo pensamento de um intelectual claramente identificado com um regime político situado à margem esquerda do espectro político latino-americano da época. 0 principal fruto de sua embaixada carioca foi, 
no entanto, a incorporação do Brasil à sua visão da América Latina, e dos escritores brasileiros à sua rede epistolar cada vez mais ampla. Esse fato certamente contribuiu para a inclusão de ensai os clássicos de interpretação da identidade nacional, como os livros de Gilberto Freyree deSérgio Buarque de $\mathrm{H}$ olanda, na coleção "Tierra Firme" da FCE, uma década mais tarde, e serviu também - como tudo parece indicar - para que Pedro H enríquez U reña - que até os anos de 1930 se abstivera de explorar a cultura brasileira - se aproximasse com entusiasmo da produção literária do Brasil.

O longo périplo americano de Reyes se aproximava do fim em 1936. N esse ano, foi enviado novamente a Buenos Aires, onde permaneceria até dezembro de 1937. D isposto a reafirmar suas alianças no campo intelectual argentino, desta vez encontrou um contexto cultural e político distinto do de sua embaixada anterior. A primeira intervenção militar (1930-1932), seguida da restauração de uma institucionalidade republicana frágil e não inteiramente legítima, havia tendido a crispar as divisões ideológicas latentes. M ais: o impacto da G uerra C ivil espanhola, num país onde a presença de imigrantes espanhóis de primeira ou segunda geração era maciça, havia transformado o campo intelectual dos anos de 1920 - mais propenso à colaboração eà transigência entre intelectuais com posições políticas divergentes - num cenário de batal ha atravessado pelo crescente confronto entre "fascistas" e "antifascistas". U m projeto ideológico e geracionalmente eclético como o definido pela revista $N$ osotros desde a sua fundação (e que as vanguardas dos anos de 1920, cabe assinalar, haviam questionado às vezes com grande estridência) mostrava-se agora impossível. Se Reyes, obrigado pela nova conjuntura a definir suas alianças locais, não titubeou, isso talvez se deva em parte ao fato de o alinhamento político-ideológico e 0 estético, no seu caso, permanecerem felizmente unidos. As constelações da Sur, de H enríquez U reña e outros membros do Instituto de Filologia, e dos irmãos R omero e seus aliados platenses, pertenciam todas ao campo "antifascista". Além disso, quase todos os antigos amigos e colaboradores de Reyes na Espanha haviam se inclinado à causa republicana. Em 1937, ano deseu retorno a Buenos Aires, 0 Centro deEstudos $\mathrm{H}$ istóricos fora obrigado a transferir-se para longe dos bombardeios que ameaçavam $M$ adri, enquanto prosseguia seu esforço heróico de edição da Revista de Filología Española e de sua nova publicação, dedicada à história, "Tierra Firme". Ainda que não fosse muito gratificante a lembrança do tédio, dos amigos, dos trabalhos e dos dias passados naquele Centro em seus longos anos madrilenhos, Reyes não pôde deixar de se sentir também galvanizado, pas- 
26. Condenado, portanto, a um férreo ostracismo social, como pôde comprovar M aría Rosa O liver por ocasião desua visita em 1939: todavez que ela propunha a seus amigos mexicanos ir visitar Reyes, surgia uma série de obrigações pré vias que tornavam impossivivel tal reunião. Em seusprimeirosanospelo menos, o único amigo fiel pareceter sido C osío Villegas. sando a desenvolver nos meios portenhos uma campanha ativa, primeiro em favor da causa republicana e depois em favor dos exilados da Segunda República. Além disso, interveio em casos de grande repercussão internacional e solução bastante delicada: por exemplo, atuou abertamente para que o governo mexicano concedesse asilo ao célebre escritor - comunista e discípulo de Josélngenieros - Aníbal Ponce, quando este se tornou alvo de uma perseguição sistemática.

Claramente identificado com a causa dos republicanos espanhóis, talvez demasiadamente, do ponto de vista dos protocolos que costumam reger as transações da diplomacia, ele recebeu no final de 1937 a notícia concisa de que seu posto fora suprimido ea ordem de retornar à pátria. Sem saber pre cisamente que destino o aguardaria num país ao qual, durante tantos anos, Ihefora aconsel hado não voltar, ele acreditou ter chegado ao fim de seu longo périplo americano. M as a situação mexicana desta vez mostrou-se mais favorável a seus futuros empreendimentos culturais. Tendo nacionalizado a indústria do petróleo e enfrentando um duro embargo por parte dasindústrias petrolíferas dos Estados U nidos eda G rã-Bretanha, o então presi dente Lázaro Cárdenas (1934-1940) decidiu valer-se do conhecimento adquirido por Reyes em seus seis anos no Rio de Janeiro para enviá-lo uma última vez ao Brasil como negociador de um acordo entre os dois países sobre as futuras compras de petróleo mexicano. A negociação - feita num clima bastante tenso - resolveu-se com êxito, de modo que Reyes, embora continuasse sendo uma espécie de pária aos olhos do partido governante ${ }^{26}$, pôde contar com o apoio do cardenismo para os projetos institucionais que dese java empreender: a criação da Casa de España, em 1938, e do Colegio de M éxico - projetado como um centro universitário de elite- em 1940. Com a anuência de Cárdenas, ele ocupou a presidência de ambas as instituições em rápida sucessão (da C asa, de 1938 a 1940, e do Colegio, de 1940 a 1959). Entrincheirado na direção do Colegio - que rapidamente se tornou a vitrina mais importante dos progressos culturais e educativos al cançados pela Revolução - , Reyes lançaria outros projetos seus, como a revista intelectual de orientação americanista Cuadernos Americanos, que, constituída como um fórum para a discussão de problemáticas transnacionais, ajudaria a promover em todo o continente a circulação da produção intelectual latino-americana. Estreitamente associado desde o início com D aniel Cosío V illegas - o historiador que começava então a dar forma a sua grande revisão crítica da "República R estaurada" e do "Porfiriato" - , colaborou também com o projeto editorial lançado por ele: o Fondo de Cultura E conómi- 
ca. Em meados dos anos de 1940, Reyes era o epicentro de uma vasta rede epistolar, queincluía ensaístas, poetas, historiadores, sociólogos, pintores e críticos de arte - entre muitas outras especialidades intelectuais - estabelecidos em Cuba, Venezuela, Colômbia, Argentina, Peru, Espanha, no resto dos países hispano-americanos e no Brasil, e também, é claro, no M éxico; assim, pôde utilizar sua posição para incidir de um modo decisivo sobre a formulação do temário - ou índice, sesequiser - do projeto deuma história cultural latino-americana ${ }^{27}$. Em menos de uma década, Alfonso Reyes, 0 "Euforión", resgataria das águas do esquecimento essa "Atlântida submersa" que era a memória cultural da América Latina, edificando com os livros da nova coleção, inéditos, traduzidos ou reeditados, a "Tierra Firme" da história cultural ibero-americana.

\section{Referências Bibliográficas}

Aguillar Cam ín, H éctor. (1977), La frontera nómada: sonora y la Revolución M exicana. M éxico, Siglo XXI.

AuerbaCH, Erich. (2001), Introduzione alla filologia romanza. 1ª̣ edição 1963. Torino, Einaudi.

Bourdieu, Pierre. (1994), Raisons pratiquess sur la théorie de l'action. Paris, Seuil. . (2002), "Les conditions de la circulation internationale des idées". Actes de la Recherche en Sciences Sociales, Paris, Seuil, n. 145, dez.

Coluins, Randall. (1998), The sociology of philosophies a global theory of intellectual change. Cambridge, Mass., Belknap H arvard.

Colom BI, Beatriz. (2004), "Alfonso Reyes y la cultura del viaje". In: Viaje intelectual, migracionesy desplazamientos en América Latina (1880-1915). Rosario, B eatriz Viterbo Editora.

Cosio Villegas, D aniel. (1963-1972), H istoria moderna de M éxico: el Porfiriato. M é xico, Editorial Hermes, vols. V-X.

. (1977), M emorias. M éxico, D.F., Joaquín M ortiz Editor.

D on oso, Armando. (1925), La otra América. M adrid, Calpe, Colección Contemporánea. Ellison, Fred P. (2002), Alfonso Reyes e o Brasil: um mexicano entre os cariocas. Rio de Janeiro, Topbooks.

FreYre, Gilberto. (1968), Como e por que sou e não sou sociólogo. Braślia, Editora da UnB.

Garciadiego, Javier. (2002), Alfonso Reyes. M éxico, Planeta/D eAgostini.

Gálvez, M anuel. (2002), Recuerdos de la vida literaria. Buenos Aires, Taurus, vol. 1, p. 656.56
27. No contexto do isolamento mexicano, podese entender perfeitamente por que a estra tégia dealiançascom figuras destacadas dos demaiscamposintelectuais nacionais da América Latina e, mais ainda, 0 projeto deconstituir um grandecampo intelectual transnacional tenham tido tanta importância para Reyes. Sobre esse tema, ver as observações 
Grignon, Claude \& PASSeron, Jean-Claude. (1991), Lo culto y lo popular: miserabilismo y populismo en sociología y en literatura. Buenos Aires, N ueva V isión. Guzmán, Martín Luis. (1915), La querella de M éxico. M adrid, Imprenta Clásica Española. .. (1928), El águila y la serpiente. M adrid, s.e. . (1929), La sombra del caudillo, M adrid, Espasa-Calpe.

Henriquez Ureña, Pedro. (1910a), "Conferencias". In: . Horas de estudio.

Paris, Librería P. Ollendorf. . (1910b), "El positivismo independiente". In: H oras de estudio. Paris,

Librería P. Ollendorf. . (1928), Seis ensayosen busca denuestra expresión. Buenos Aires/M adrid, Babel. - (1947), H istoria de la cultura en la América hispánica. M éxico, FCE. . (1975), D esde Washington. La H abana, Casa de las Américas. . (1978), La utopía de América. Caracas, Biblioteca Ayacucho. . (1989), M emorias/diario. Buenos Aires, Academia Argentina de Letras. . (2000), Ensayos. Buenos Aires, ALLCA XX/Editorial Sudamericana, Colección Archivos.

I n o A, O rlando. (2002), Pedro H enríquez U reña en Santo D omingo. Santo D omingo, Comisión Permanente de la Feria del Libro.

Katz, Friedrich. (1998), The life and times of Pancho Villa. Stanford, Stanford University Press.

KNIGHT, Alan. (1986), The M exican Revolution. Cambridge, Cambridge University Press, 2 vols.

Krause, Enrique. (1985), Caudillos culturales en la Revolución M exicana. M éxico, SEPCultura.

LARA, Juan Jacobo de. (1975), Pedro H enríquez U reña: su vida y su obra. Santo D omingo, Universidad Nacional Pedro H enríquez U reña.

Lomnitz-Adler, Claudio. (1992), Exits from the labyrinth: culture and ideology in M exican national space. Los Angeles/Berkeley, California U niversity Press. M ARtín EZ, JoséLuis. (1992), Guía para la navegación deAlfonso Reyes. M éxico, U nam. M on siváls, Carlos. (1976), "N otas sobre la cultura mexicana en el siglo XX". H istoria general de M éxico. M éxico, El Colegio de M éxico, vol. 2.

N eIBURG, Federico \& PLOTKIn , M ariano. (2004), Intelectualesy expertos. la constitución del conocimiento social en la Argentina. Buenos Aires, Paidós. N ovo, Salvador. (1935), C ontinente vacío: viaje a Sudamérica. M adrid, Espasa-C alpe. O liver, M aríaRosa. (1969), La vida cotidiana. Buenos Aires, Editorial Sudamericana. O RTIZ, Fernando. (1947), El huracán: su mitología y sus śmbolos. M éxico, FCE. 
. (1949), "Los factores humanos de la cubanidad". Revista Bimestre Cubano,

La H abana, XLV (3), mar.-abr. (reeditado em O RTIz, Fernando. Etnia y sociedad. La H abana, Editorial de Ciencias Sociales, 1993).

Patout, Paulette. (1990), Alfonso Reyes y Francia. M éxico, El Colegio de M éxico.

ReYes, Alfonso. (1962), "Pasado inmediato". Conferencias del Ateneo de la Juventud. 1’a edição 1941. M éxico, U nam.

Reyes Jurado, Alicia. (1972), Genio y figura de Alfonso Reyes. Buenos Aires, Eudeba. Robledo Rincón, Eduardo (coord.). (1999), Alfonso Reyesen Argentina. BuenosAires, Instituto de Cultura de Aguascalientes.

Sarlo, Beatriz. (2002), "Recuerdos de un escritor profesional”. In: Gálvez, M anuel. Recuerdos de la vida literária. Buenos Aires, Taurus, vol. 1.

SCHMIDT, H enry C. (1978), The roots of "Lo mexicano": self and society in M exican thought, 1900-1934. Texas, A\& M University Press/C ollege Station.

Sherid An, Guillermo. (1985), Los contemporáneos ayer. M éxico, FCE.

Sim mel, Georg. (1997), "Sociology of the senses". In: Frisby, D avid \& Featherstone, $M$ ike (orgs.). Simmel on culture. London, Sage Publications.

So RÁ, Gustavo. (2004), "Editores y editoriales de ciencias sociales: un capital específico". In: NeIburg, Federico \& Plotkin, M ariano. Intelectuales y expertos: la constitución del conocimiento social en la Argentina. Buenos Aires, Paidós.

VÁrıos. (1974-1981), H istoria de la Revolución M exicana. M éxico, D .F., El Colegio de M éxico, 24 vols.

Villegas, Abelardo. (1993), El pensamiento mexicano en el siglo XX. M éxico, FCE.

W ILLIS, James Robb. (1965), El estilo de Alfonso Reyes imagen y estructura. M éxico, FCE.

WomAck, John. (1969), Zapata and the M exican Revolution. New York, Alfred A. Knopf.

ZeA, Leopoldo. (1968), El positivismo en M éxico. M éxico, FCE.

Zuleta Álvarez, Enrique. (1997), Pedro H enríquez U reña y su tiempo. Buenos Aires, C atálogos Editora.

\section{Resumo}

Gênese "ateneísta" da história cultural lanino-americana

Este trabal ho analisa a formação de uma rede transnacional deintelectuais, os "ateneístas" - um grupo intelectual constituído originalmente no M éxico em torno da dupla experiência do Ateneo de la Juventud e da participação nas diversas iniciativas culturais (em especial a criação da Universidade $\mathrm{N}$ acional do $\mathrm{M}$ éxico) promovidas pelos governos da Revolução M exicana - , e seu papel nas origens da história cultural da América Latina. As trajetórias intel ectuais de seus membros mais importantes - Pedro 
Texto recebido em 29/ 4/2004 eaprovado em 18/11/2004.

Jorge M yers é professor titular de história cultural argentina e membro do Programa de Historial ntelectual do Centro deEstudosel nvestigação naUniversidadedeQ uilmes; investigador do Conicet, autor do livro O rden y virtud: el discurso republicanode régimen rosisa (1995), eco-compilador de Resonandasrománticas nuevasmiradas sobrela hisoria cultural argentina del siglo XIX (no prelo).E-mail: jmyers@ unq.edu.ar.
H enríquez U reña e Alfonso Reyes - eque contribuíram para a formação de um circuito intelectual que vinculava entre si os campos intelectuais mexicano, argentino, espanhol e brasileiro, são examinadas com certo detalhe. 0 propósito do trabal ho éduplo: de um lado, se propõe a explorar a relação entre a circulação internacional de idéias e as condições para a emergência de novas formações culturais no interior dos campos intelectuais nacionais; e, de outro, analisar o processo específico pelo qual tomou corpo - por meio da confluência entre obras específicas, de projetos editoriais, de instituições culturais e de intercâmbios ou contatos culturais entre os distintos países iberoamericanos- um discurso historiográfico com características novas na região. 0 período compreendido é o que vai aproximadamente de 1906 a 1960.

Palavras-chave: Ateneístas; $\mathrm{H}$ istória cultural latino-americana; Rede de intelectuais.

\section{Abstract}

The "Ateneísta" origin of Latin American cultural history

In this article, the formation of a transnational network of intellectuals, that of the "Ateneistas" - a group which was originally constituted in M exico through the double experience of the "Ateneo de la Juventud" and of participation in the various cultural initiatives promoted by the Revolutionary governments of $M$ exico (and especially in the creation of the U niversidad $\mathrm{N}$ acional de $\mathrm{M}$ éxico) - , is analyzed; as is its role in the origins of the cultural history of Latin America. The intellectual trajectories of two of its most prominent members - which, through their agency, contributed to the formation of an intellectual network linking the national intellectual fields of M exico, Argentina, Spain and Brasil - are examined in some detail: those of Pedro H enríquez U reña and Alfonso Reyes. The purpose of this study is dual. It proposes an exploration, on the one hand, of the relationship between the international circulation of ideas and the conditions for the emergence of new cultural formations within national intellectual fields. It seeks, on the other hand, to analyze the specific process whereby a historiographical discourse with novel characteristics took shape in the region through the agency of a confluence of specific works, publishing projects, cultural institutions, and cultural contacts among the different countries of I beroamerica. The period covered is roughly that which stretches from 1906 to 1960.

Keywords: "Ateneístas"; Latin-american cultural history; N etwork of intellectuals. 